\title{
SENTENCIAS Y AUTOS DEL TRIBUNAL SUPREMO Y RESOLUCIONES DE LA DIRECCION GENERAL DE LOS REGISTROS EN QUE SE CITAN, ESTUDIAN O APLICAN PRECEPTOS CONSTITUCIONALES (AÑO 1981. Conclusión)
}

\author{
POR \\ ENRIQUE LINDE PANIAGUA \\ Universidad Nacional de Educación a Distancia
}

\begin{abstract}
SUMARIO
1. Indice cronológico: A) Sentencias y autos del Tribunal Supremo; B) Resoluciones de la Dirección General de los Registros.-2. Indice de corres. pondencias a los artículos de la Constitución, de las sentencias y autos del Tribunal Supremo y resoluciones de la Dirección General de los Registros $y$ del Notariado.-3. Indice de materias que de modo principal se estudian en las sentencias y autos del Tribunal Supremo y en las resoluciones de la Dirección General de los Registros y del Notariado.-4. Repertorio de 1981

(conclusión).
\end{abstract}

\section{INDICE CRONOLOGICO 1981}

\section{A) Sentencias y autos del Tribunal Supremo}

Núm. 1. Auto de 19 de enero de 1981. Civil. Ponente, J. de Castro García: Artículo 32.2 de la Constitución.

Núm. 2. Sentencia de 28 de enero de 1981. Contencioso-Administrativo. Sala V. Ponente, J. Díaz de Lope-Díaz y López: Artículos 9.3 y 24 de la Constitución.

Núm. 3. Sentencia de 7 de febrero de 1981. Criminal. Ponente, B. Gil Sáez. Constitución.

Núm. 3 bis. Sentencia de 13 de febrero de 1981. Criminal. Ponente, B. F. Castro Pérez: Artículo 20 de la Constitución.

Núm. 4. Sentencia de 17 de febrero de 1981. Contencioso-Administrativo. Sala IV. Ponente, J. M. Ruiz-Jarabo Ferrán: Artículo 24.2 de la Constitución.

Núm. 5. Sentencia de 20 de febrero de 1981. Contencioso-Administrativo. Sala V. Ponente, A. Agúndez Fernández: Artículos 9.1, 97 y 103 de la Constitución.

Núm. 6. Sentencia de 21 de febrero de 1981. Contencioso-Administrativo. Sala IV. Ponente, A. Martín del Burgo y Marchán: Artículo 33 de la Constitución.

Núm. 7. Sentencia de 27 de febrero de 1981. Contencioso-Administrativo. Sala V. Ponente, F. de Mateo Lage: Artículo 106.2 de la Constitución. 
Núm. 8. Sentencia de 21 de marzo de 1981. Civil. Ponente, J. Castro García: Artículo 28.1 de la Constitución.

Núm. 8. bis. Sentencia de 23 de marzo de 1981. Contencioso-Administrativo. Sala IV. Ponente, F. Fernández Tejedor: Artículo 104 de la Constitución.

Núm. 9. Auto de 27 de marzo de 1981. Criminal. Ponente, B. Gil Sáez: Artículo 117.5 de la Constitución.

Núm. 9 bis. Sentencia de 31 de marzo de 1981. Contencioso-Administrativo. Sala III. Ponente, J. L. Martín Herrero: Artículo 140 de la Constitución.

Núm. 10. Auto de 1 de abril de 1981. Criminal. Ponente, F. Gotta y Márquez de Prado: Artículo 24 de la Constitución.

Núm. 11. Sentencia de 3 de abril de 1981. Criminal. Ponente, B. F. Castro Pérez: Artículo 12 de la Constitución.

Núm. 11 bis. Sentencia de 7 de abril de 1981. Contencioso-Administrativo. Sala III. Ponente, D. Espín Cánovas: Artículo 27 de la Constitución.

Núm. 12. Sentencia de 8 de abril de 1981. Criminal. Ponente, J. H. Moyna Ménguez: Artículo 16.1 y 3 de la Constitución.

Núm. 12 bis. Sentencia de 11 de abril de 1981. Contencioso-Administrativo. Sala IV. Ponente, Angel Martín del Burga y Marchán: Artículo 137 de la Constitución.

Núm. 12 ter. Sentencia de 11 de abril de 1981. Contencioso-Administrativo. Sala III. Ponente, M. Sainz Arenas: Artículos 97 y 103 de la Constitución.

Núm. 13. Auto de 23 de abril de 1981. Criminal. Ponente, M. Gómez de Liaño y Cobaleda: Artículos 24.2 y 53.1 de la Constitución.

Núm. 14. Sentencia de 29 de abril de 1981. Criminal. Ponente, M. Gómez de Liaño y Cobaleda: Artículo 24 de la Constitución.

Núm. 15. Sentencia de 7 de mayo de 1981. Criminal. Ponente, M. Gómez de Liaño Cobaleda: Artículo 24 de la Constitución.

Núm. 16. Sentencia de 8 de mayo de 1981. Civil. Ponente, C. de la Vega Benayas: Artículos 39.2 y 53.3 de la Constitución.

Núm. 17. Sentencia de 13 de mayo de 1981. Criminal. Ponente, B. F. Castro Pérez: Artículos 24 y 53 de la Constitución.

Núm. 18. Sentencia de 22 de mayo de 1981. Contencioso-Administrativo. Sala III. Ponente, M. Gordillo García: Artículos 10, 13.1, 14, 19 y 96 de la Constitución.

Núm. 19. Sentencia de 22 de mayo de 1981. Criminal. Ponente, M. Gómez de Liaño Cobaleda: Artículo 71 de la Constitución.

Núm. 20. Sentencia de 28 de mayo de 1981. Criminal. Ponente, M. Gómez de Liaño y Cobaleda: Artículo. 24 de la Constitución.

Núm. 21. Sentencia de 2 de junio de 1981. Contencioso-Administrativo. Sala IV. Ponente, E. Medina Balsameda: Artículo 24.1 de la Constitución.

Núm. 22. Sentencia de 10 de junio de 1981. Contencioso-Administrativo. Sala III. Ponente, D. Espín Cánovas: Artículo 24 de la Constitución.

Núm. 23. Sentencia de 11 de junio de 1981. Criminal. Ponente, J. Latour Brotons: Artículo 106.2 de la Constitución.

Núm. 24. Sentencia de 15 de junio de 1981. Contencioso-Administrativo. Sala III. Ponente, D. Espín Cánovas: Artículos 133.2 y 140 de la Constitución.

Núm. 25. Sentencia de 17 de junio de 1981. Contencioso-Administrativo. Sala III. Ponente, D. Espín Cánovas: Artículos 9 y 133 de la Constitución.

Núm. 26. Sentencia de 19 de junio de 1981. Contencioso-Administrativo. Sala III. Ponente, D. Espín Cánovas: Artículo 9 de la Constitución. 
Núm. 26 bis. Sentencia de 2 de julio de 1981. Contencioso-Administrativo. Sala IV. Ponente, A. Botella y Taza: Constitución.

Núm. 27. Sentencia de 7 de julio de 1981. Contencioso-Administrativo. Sala III. Ponente, J. Pérez Fernández: Artículo 23 de la Constitución:

Núm. 28. Sentencia de 7 de julio de 1981. Givil. Ponente, J. de Castro García: Artículos 7 y 28 de la Constitución.

Núm. 29. Sentencia de 8 de julio de 1981: Criminal. Ponente, M. García Miguel: Artículos 18 y 20 de la Constitución.

Núm. 30. Sentencia de 9 de julio de 1981. Contencioso-Administrativo. Sala IV. Ponente, E. Díaz Eimil: Artículos 9.1, 21 y 53.1, y disposición derogatoria tercera de la Constitución.

Núm. 31. Sentencia de 15 de septiembre de 1981. Contencioso-Administrativo. Sala III. Ponente, J. Pérez Fernández: Artículos 9, 14, 20, 27 y. 53.2 de la Constitución.

Núm. 32. Sentencia de 17 de septiembre de 1981. Social. Ponente, J. González Encabo: Artículo 35.2 de la Constitución.

Núm. 33. Sentencia de 22 de septiembre de 1981. Contencioso-Administrativo. Sala IV. Ponente, E. Díaz Eimil: Artículos 10.2 y 96.1 de la Constitución.

Núm. 34. Sentencia de 23 de septiembre de 1981: Contencioso-Administrativo. Sala IV. Ponente, P. Martín Martín: Artículos 10.2, 13.1, 24.1.y 96 de la Constitución.

Núm. 35. Sentencia de 30 de septiembre de 1981. Contencioso-Administrativo. Sala III. Ponente, D. Espín Cánovas: Artículos 46 y 47.2 de la Constitución.

Núm. 36. Sentencia de 7 de octubre de 1981. Contencioso-Administrativo. Sala IV. Ponente, E. Medina Balmaseda: Artículos 6, 23 y 53 de la Constitución.

Núm. 37. Sentencia de 13 de octubre de 1981. Contencioso-Administrativo. Sala III. Ponente, J. Fernández Santamaría: Artículos 9.1, 28.2 y 53.1 $y$ disposición derogatoria tercera de la Constitución.

Núm. 38. Sentencia de 13 de octubre de 1981. Contencioso-Administrativo. Sala IV. Ponente, A. Martín del Burgo y Marchán: Artículo 53.2 de la Constitución.

Núm. 39. Sentencia de 13 de octubre de 1981. Contencioso-Administrativo. Sala IV. Ponente, E. Díaz Eimil: Artículo 24.1 de la Constitución.

Núm. 40. Sentencia de 13 de octubre de 1981. Contencioso-Administrativo. Sala IV. Ponente, J. M. Ruiz-Jarabo Ferrán: Artículo 9.2 de la Constitución.

Núm. 41. Sentencia de 14 de octubre de 1981. Contencioso-Administrativo. Sala IV. Ponente, P. Martín Martín: Artículo 24 y disposición derogatoria tercera de la Constitución.

Núm. 42. Sentencia de 15 de octubre de 1981: Contencioso-Administrativo. Sala V. Ponente, A. Agúndez Fernández: Artículo 117.1 y 2 de la Constitución.

Núm. 43. Sentencia de 16 de octubre de 1981. Social. Sala VI. Ponente, E. Rams Catalán: Mera cita de la Constitución.

Núm. 44. Sentencia de 16 de octubre de 1981. Sala de Competencias. Ponente, E. Torres-Dulce Ruiz: Artículo 24 de la Constitución.

Núm. 45. Sentencia de 19 de octubre de 1981. Contencioso-Administrativo. Sala III. Ponente, J. L. Ruiz Sánchez: Artículo $7.28^{\circ} y$ disposición derogatoria de la Constitución. 
Núm. 46. Sentencia de 19 de octubre de 1981. Contencioso-Administrativo. Sala IV. Ponente, E. Díaz Eimil: Artículo 103.1, mera cita, de la Constitución.

Núm. 47. Sentencia de 20 de octubre de 1981. Contencioso-Administrativo. Sala IV. Ponente, E. Díaz Eimil: Artículo 137 de la Constitución.

Núm. 48. Sentencia de 20 de octubre de 1981. Contencioso-Administrativo. Sala V. Ponente, A. Falcón García: Artículo 106 de la Constitución.

Núm. 49. Sentencia de 22 de octubre de 1981. Contencioso-Administrativo. Sala IV. Ponente, P. Martín Martín: Artículos 97 y 106 de la Constitución.

Núm. 50. Sentencia de 27 de octubre de 1981. Contencioso-Administrativo. Sala IV. Ponente, J. M. Ruiz-Jarabo Ferrán: Artículos 22.2.3 y 5 y 53.2 de la Constitución.

Núm. 51. Sentencia de 28 de octubre de 1981. Contencioso-Administrativo. Sala III. Ponente, D. Espín Cánovas: Artículo 9 de la Constitución.

Núm. 52. Sentencia de 29 de octubre de 1981. Contencioso-Administrativo. Sala V. Ponente, P. García Manzano: Artículo 26 de la Constitución.

Núm. 53. Sentencia de 31 de actubre de 1981. Criminal. Ponente, M. García Miguel: Artículo 39.2 de la Constitución.

Núm. 54. Sentencia de 31 de octubre de 1981. Criminal. Ponente, M. Gómez de Liaño y Cobaleda: Artículo 20 de la Constitución.

Núm. 55. Sentencia de 3 de noviembre de 1981. Contencioso-Administrativo. Sala IV. Ponente, E. Díaz Eimil: Artículos 10, 13.1, 14, 19, 24 y 96 de la Constitución.

Núm. 56. Sentencia de 4 de noviembre de 1981. Contencioso-Administrativo. Sala IV. Ponente, P. Martín Martín: Articulo 22.3 de la Constitución.

Núm. 57. Sentencia de 12 de noviembre de 1981. Social. Ponente, J. García Murga Vázquez: Artículo 24.1 de la Constitución.

Núm. 58. Sentencia de 17 de noviembre de 1981. Contencioso-Administrativo. Sala IV. Ponente, P. Martín Martín: Artículos 24, 53, 97 y disposición derogatoria tercera de la Constitución.

Núm. 59. Sentencia de 19 de noviembre de 1981. Criminal. Ponente, F. Cotta y Márquez de Prado: Artículo 20.4 de la Constitución.

Núm. 60. Sentencia de 20 de noviembre de 1981. Civil. Sala I. Ponente, A. Sánchez Jáuregui: Artículos 28, 36 y 52 de la Constitución.

Núm. 61. Sentencia de 25 de noviembre de 1981. Contencioso-Administrativo. Sala IV. Ponente, E. Díaz Eimil: Artículo 33.2 de la Constitución.

Núm. 62. Sentencia de 25 de noviembre de 1981. Contencioso-Administrativo. Sala IV. Ponente, J. M. Sánchez Andrade y Sal: Artículo 28 de la Constitución.

Núm. 63. Sentencia de 27 de noviembre de 1981. Contencioso-Administrativo. Sala V. Ponente, J. Díaz de Lope-Díaz y López: Artículos 14 y 33 de la Constitución.

Núm. 64. Sentencia de 28 de noviembre de 1981. Civil. Sala I. Ponente, A. Fernández Rodríguez: Artículos 10, 14, 32.1 y 57 de la Constitución.

Núm. 65. Sentencia de 28 de noviembre de 1981. Contencioso-Administrativo. Sala IV. Ponente, P. Martín Martín: Artículo 24 de la Constitución.

Núm. 66. Sentencia de 30 de noviembre de 1981. Contencioso-Administrativo. Sala V. Ponente, P. García Manzano: Artículos 103.1 y 106.1 de la Constitución.

Núm. 67. Sentencia de 1 de diciembre de 1981. Contencioso-Administrativo. Sala V. Ponente, F. Mateo Lage: Artículo 164.1 de la Constitución.

Núm. 68. Auto de 3' de diciembre de 1981. Criminal. Sala II. Ponente, L. Vivas Marzal: Articulo 117.5 de la Constitución. 
Núm. 69. Sentencia de 3 de diciembre de 1981. Contencioso-Administrativo. Sala III. Ponente, J. L. Ruiz Sánchez: Artículo 96 de la Constitución.

Núm. 70. Sentencia de 4 de diciembre de 1981. Contencioso-Administrativo. Sala V. Ponente, J. Díaz de Lope-Díaz y López: Articulo 14 de la Constitución.

Núm. 71. Sentencia de 5 de diciembre de 1981. Criminal. Sala II. Ponente, L. Vivas Marzal: Artículo 20 de la Constitución.

Núm. 72. Sentencia de 7 de diciembre de 1981. Contencioso-Administrativo. Sala III. Ponente, D. Espín Cánovas: Constitución.

Núm. 73. Sentencia de 12 de diciembre de 1981. Criminal. Sala II. Ponente, F. Cotta y Márquez de Prado: Artículos 18.4 y 20 de la Constitución.

Núm. 74. Auto de 17 de diciembre de 1981. Contencioso-Administrativo. Sala III. Ponente, M. Pérez Tejedor: Articulos 14 y sección $1 .^{a}$ del capítulo 2. ${ }^{\circ}, 18$ y 53.2 de la Constitución.

Núm. 75. Sentencia de 18 de diciembre de 1981. Contencioso-Administrativo. Sala V. Ponente, P. García Manzano: Artículo 9.3 de la Constitución.

Núm. 76. Sentencia de 21 de diciembre de 1981. Criminal. Sala II. Ponente, L. Vivas Marzal: Artículo 15 de la Constitución.

Núm. 77. Sentencia de 22 de diciembre de 1981. Contencioso-Administrativo. Sala III. Ponente, D. Espín Cánovas: Artículo 47 de la Constitución.

Núm. 78. Sentencia de ' 26 de diciembre de 1981. Criminal. Sala II. Ponente, M. Gómez de Liaño y Cobaleda: Artículo 24 de la Constitución.

Núm. 79. Sentencia de 29 de diciembre de 1981. Criminal. Sala II. Ponente, J. Latour Brotons: Artículos 14 y 25 de la Constitución.

\section{B) Resoluciones de la Dirección General de los Registros}

R. 1. Resolución de 14 de enero de 1981.

R. 2. Resolución de 28 de enero de 1981.

R. 3. Resolución de 6 de abril de 1981 .

R. 4. Resolución de 30 de junio de 1981.

R. 5. Resolución de 2 de octubre de 1981 .

2. INDICE DE CORRESPONDENCIAS A LOS ARTICULOS DE LA CONSTITUCION, DE LAS SENTENCIAS $Y$ AUTOS DEL TRIBUNAL SUPREMO $Y$ RESOLUCIONES DE LA DIRECCION GENERAL DE LOS REGISTROS Y DEL NOTARIADO, 1981

Artículo, capítulo, título del texto constitucional
Sentencias, autos y resoluciones (se indica el número marginal de los mismos, tal y como aparecen en el Indice cronológico)

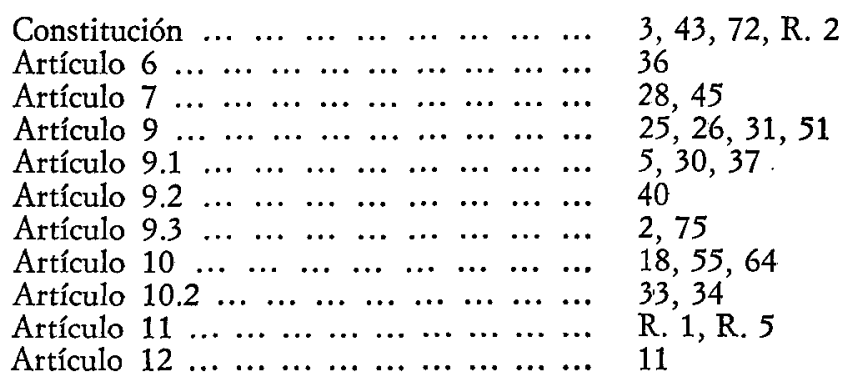

\begin{tabular}{lllllllllll}
\hline Constitución & $\ldots$ & $\ldots$ & $\ldots$ & $\ldots$ & $\ldots$ & $\ldots$ & $\ldots$ & $\ldots$ & $3,43,72$, R. 2
\end{tabular}

$\begin{array}{llllllllll}\text { Artículo } 6 & \ldots & \ldots & \ldots & \ldots & \ldots & \ldots & \ldots & \ldots & \ldots\end{array}$

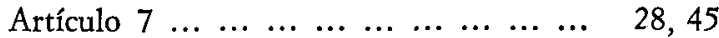

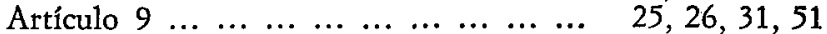

$\begin{array}{llllllllll}\text { Artículo } 9.1 & \ldots & \ldots & \ldots & \ldots & \ldots & \ldots & \ldots & \ldots & 5,30,37\end{array}$

Artículo 9.2 ...

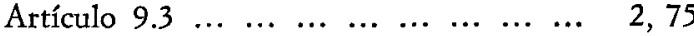

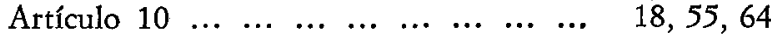

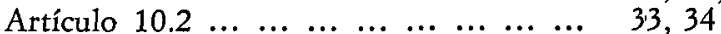

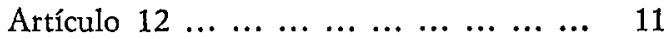


Artículo, capítulo, título del texto constitucional

Artículo $13: 1$

Artículo 14

Artículo 14 y sección 1.a del capítulo 2.\%, título 1.0

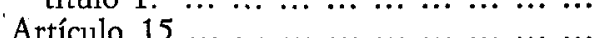

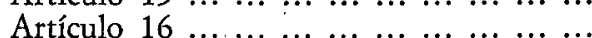

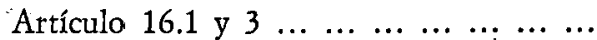

Artículo $18 \ldots \ldots \ldots \ldots$

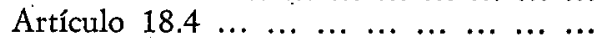

Artículo $19 \ldots \ldots \ldots \ldots$

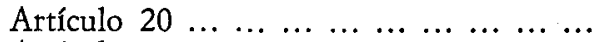

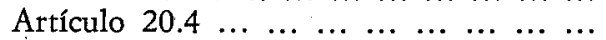

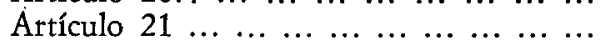

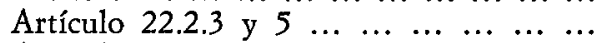

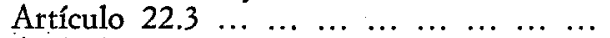

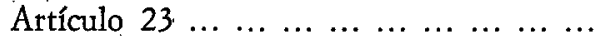

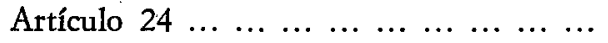

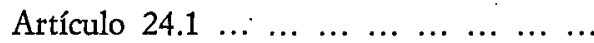

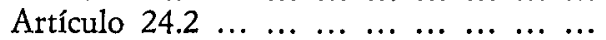

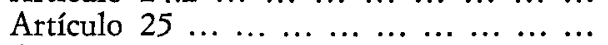

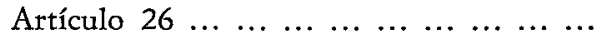

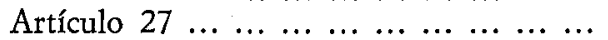

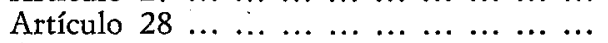

$\begin{array}{llllllllll}\text { Artículo } & 28.1 & \ldots & \ldots & \ldots & \ldots & \ldots & \ldots & \ldots & \ldots\end{array}$

Artículo $\begin{array}{llllllllll}28.2 & \ldots & \ldots & \ldots & \ldots & \ldots & \ldots & \ldots & \ldots\end{array}$

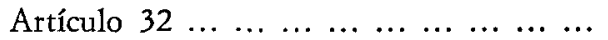

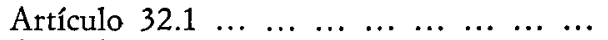

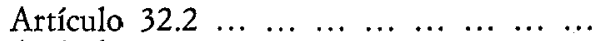

Artículo $33 \ldots \ldots \ldots \ldots \ldots \ldots$

$\begin{array}{lllllllll}\text { Artículo } 33.2 & \ldots & \ldots & \ldots & \ldots & \ldots & \ldots & \ldots & \ldots\end{array}$

Artículo $\begin{array}{llllllllll}35.2 & \ldots & \ldots & \ldots & \ldots & \ldots & \ldots & \ldots & \ldots\end{array}$

Artículo $36 \quad \ldots \ldots \ldots . \ldots \ldots$

Artículo $\begin{array}{lllllllll}39.2 & \ldots & \ldots & \ldots & \ldots & \ldots & \ldots & \ldots & \ldots\end{array}$

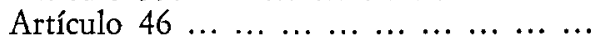

Artículo $47 \quad \ldots \ldots \ldots \ldots \ldots$

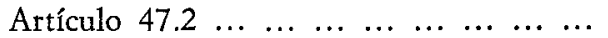

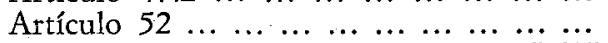

Artículo $\begin{array}{llllllllllll}53 & \ldots & \ldots & \ldots & \ldots & \ldots & \ldots & \ldots & \ldots & \ldots\end{array}$

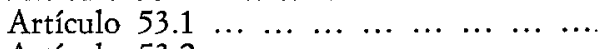

Artículo $\begin{array}{llllllllll}53.2 & \ldots & \ldots & \ldots & \ldots & \ldots & \ldots & \ldots & \ldots\end{array}$

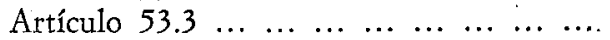

Artículo $57 \ldots \ldots \ldots \ldots . \ldots \ldots$

Artículo $\begin{array}{llllllllll}71 & \ldots & \ldots & \ldots & \ldots & \ldots & \ldots & \ldots & \ldots & \ldots\end{array}$

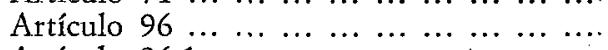

\begin{tabular}{lllllllllll} 
Artículo & 96.1 & $\ldots$ & $\ldots$ & $\ldots$ & $\ldots$ & $\ldots$ & $\ldots$ & $\ldots$ & $\ldots$ & $\ldots$ \\
\hline
\end{tabular}

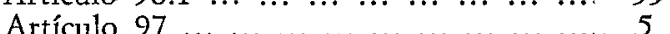

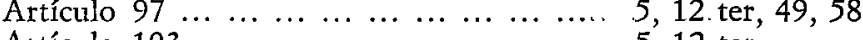

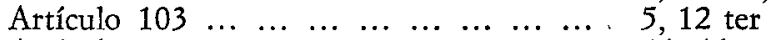

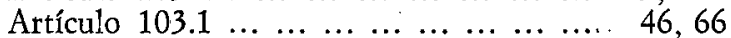

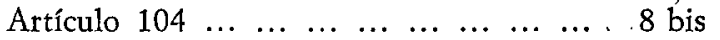

Sentencias, autos y resoluciones (se indica el número marginal de los mismos, tal y como aparecen en el Indice cronológico) .

$18,34,55$

$18,31,55,63,64,70,74,79$, R. 4

\section{4}

R. 3, R. 4

12

29,74

18,55

3 bis, $29,31,20,54,71,73$

59

50

56

27,36

$2,10,14,15,17,20,22,41,44,55$, $58,65,78$

$21,34,39,57$

4,13

79

52

11 bis, 31

$28,45,60,62$

8

R. 3

64

6,63

61

32

60

16,53

77

35

60

$17,36,58$, R. 4

$13,30,17$

$31,38,74$

16

$18,34,55,69$

$18,34,55,69$ 
Artículo, capítulo, título del texto constitucional

Artículo 106

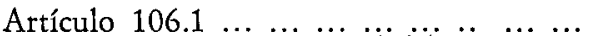

Artículo $106.2 \ldots \ldots \ldots \ldots \ldots \ldots$

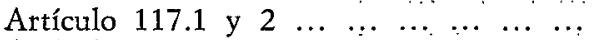

Artículo $\begin{array}{lllllllll}117.5 & \ldots & \ldots & \ldots & \ldots & \ldots & \ldots & \ldots & \ldots\end{array}$

Artículo \begin{tabular}{lllllllllll}
133 & $\ldots$ & $\ldots$ & $\ldots$ & $\ldots$ & $\ldots$ & $\ldots$ & $\ldots$ & $\ldots$ \\
\hline
\end{tabular}

Artículo $133.2 \ldots \ldots \ldots \ldots \ldots \ldots$

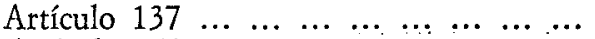

Artículo $\begin{array}{llllllllll}140 & \ldots & \ldots & \ldots & \ldots & \ldots & \ldots & \ldots & \ldots\end{array}$

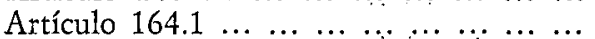

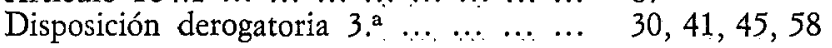

$48 ; 49$

66

7,23

42

9,68

25

24

12 bis, 47

9 bis, 24

67
Sentencias, autos y resoluciones (se indica el número marginal de los mismos, tal y como aparecen en el Indjce cronológico)

3. INDICE DE MATERIAS, 1981

Sentencias, autos y resoluciones (se indica el número

$\mathrm{M}$ a $\mathrm{t}$ e $\mathrm{r}$ i a s marginal de los' mismos, 'tal y como aparecen en el Indice cronologico)

Acceso a cargos públicos $\ldots \begin{array}{lllllllllllll} & \ldots & \ldots & \ldots & \ldots & \ldots & \ldots & \ldots & \ldots & 36\end{array}$

Acceso a la función pública: principios de méritos y ca-

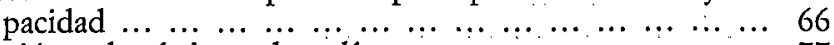

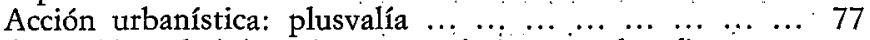

Actuación administrativa: sometimiento a los fines que

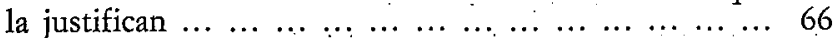

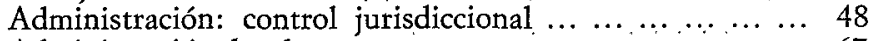

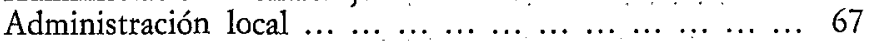

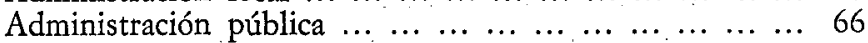

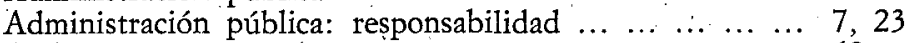

Ambito estrictamente castrense $\begin{array}{llllllllllllll} & \ldots & \ldots & \ldots & \ldots & \ldots & \ldots & \ldots & \ldots & 68\end{array}$

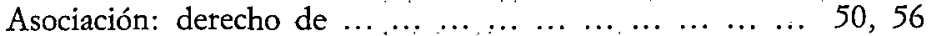

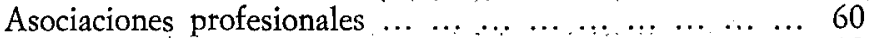

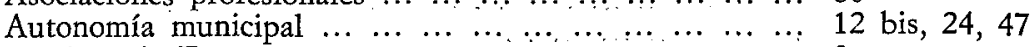

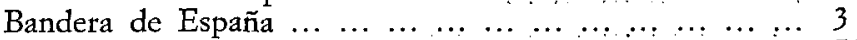

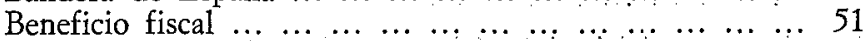

$\begin{array}{llllllllllll}\text { Colegios profesionales } & \ldots & \ldots & \ldots & \ldots & \ldots & \ldots & \ldots & \ldots & \ldots & \ldots & 60\end{array}$

Condenado: derechos $\begin{array}{lllllllllllllllllllll} & \ldots & \ldots & \ldots & \ldots & \ldots & \ldots & \ldots & \ldots & \ldots & \ldots & \ldots & \ldots & \ldots & & 79\end{array}$

Confesión religiosa: ninguna tendrá carácter estatal ..., ... 12

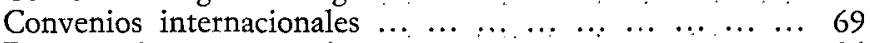

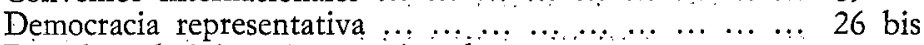

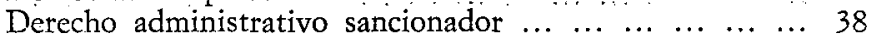

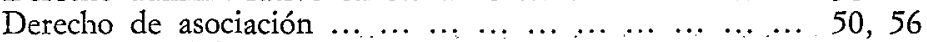

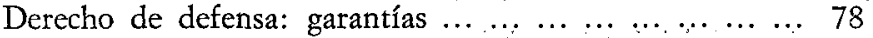

Derecho a una efectiva tutela jurisdiccional .............. 41

$\begin{array}{llllllllll}\text { Derecho al honor } & \ldots & \ldots & \ldots & \ldots & \ldots & \ldots & \ldots & \ldots & \ldots\end{array}$

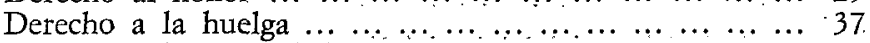

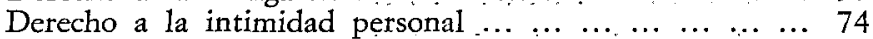

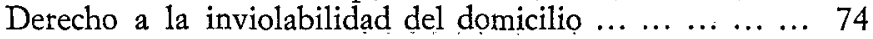




\begin{tabular}{lllll}
\hline $\mathbf{M}$ a $\mathbf{t}$ e $\mathbf{r} \mathbf{i}$ a s $\ldots$ & $\ldots$ & $\ldots$ & $\ldots$ & $\begin{array}{c}\text { Sentencias, autos y resolu- } \\
\text { clones (se indica el número } \\
\text { marginal de los mismos, tal }\end{array}$ \\
$\begin{array}{c}\text { y como aparecen en el Indi- } \\
\text { ce cronologico) }\end{array}$
\end{tabular}

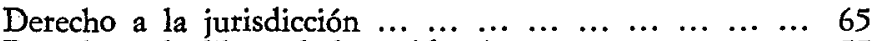

$\begin{array}{llllllll}\text { Derecho a la libertad de residencia } & \ldots & \ldots & \ldots & \ldots & \ldots & \ldots & 55\end{array}$

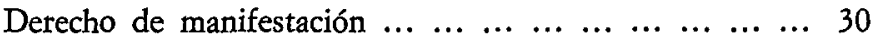

Derecho a obtener la tutela de jueces y tribunales $\ldots . . . .2 .2$

Derecho a participar en los asuntos públicos ... $\ldots \ldots \ldots . . .36$

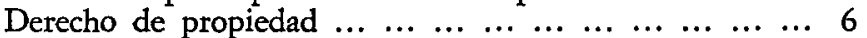

Derecho de reunión pacífica y sin armas $\ldots \ldots \ldots \ldots \ldots$

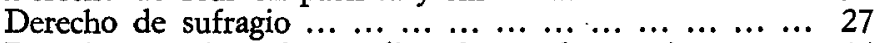

Derecho a utilizar los medios de prueba pertinentes ... $14,15,17$

$\begin{array}{llllllllllllll}\text { Discriminación } & \ldots & \ldots & \ldots & \ldots & \ldots & \ldots & \ldots & \ldots & \ldots & \ldots & \ldots & \ldots & 31\end{array}$

$\begin{array}{lllllllllllllllll}\text { Divorcio } & \ldots & \ldots & \ldots & \ldots & \ldots & \ldots & \ldots & \ldots & \ldots & \ldots & \ldots & \ldots & \ldots & \ldots & 1\end{array}$

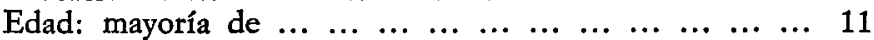

$\begin{array}{llllllllllllllllll} & \text { Enseñanza } & \ldots & \ldots & \ldots & \ldots & \ldots & \ldots & \ldots & \ldots & \ldots & \ldots & \ldots & \ldots & \ldots & \ldots & 11 & \\ \text { bis }\end{array}$

$\begin{array}{llllllllllllllllll}\text { Extranjeros } & \ldots & \ldots & \ldots & \ldots & \ldots & \ldots & \ldots & \ldots & \ldots & \ldots & \ldots & \ldots & \ldots & 33,34,55,63\end{array}$

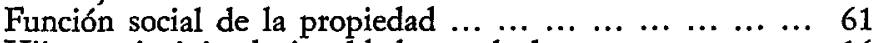

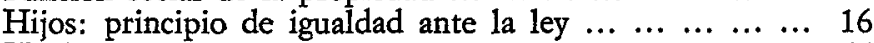

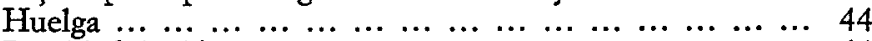

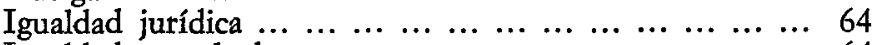

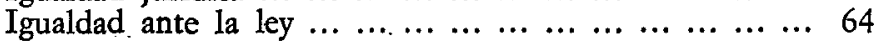

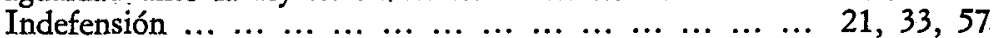

Inocencia: principio de presunción $\ldots \ldots \ldots \ldots \ldots \ldots \ldots \ldots .4,20,22$

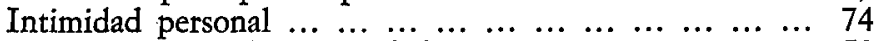

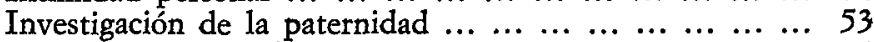

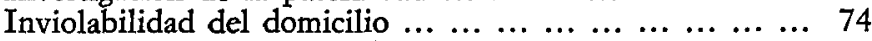

Inviolabilidad e inmunidad parlamentaria: principios de ... 19

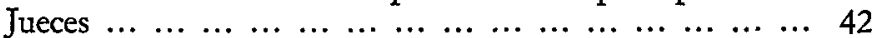

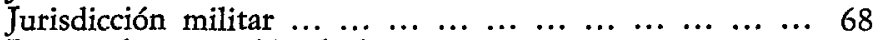

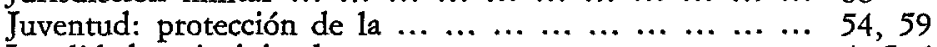

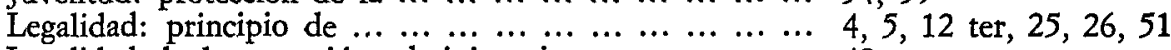

Legalidad de la actuación administrativa $\ldots \ldots \ldots \ldots \ldots$

Legitimación corporativa $\ldots \ldots \ldots \ldots \ldots \ldots$

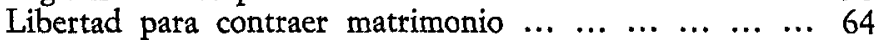

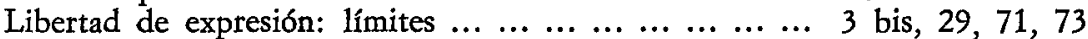

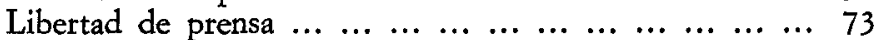

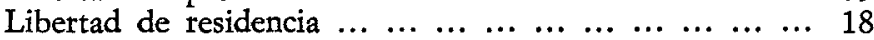

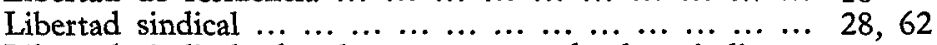

Libertad sindical: derecho a crear o fundar sindicatos

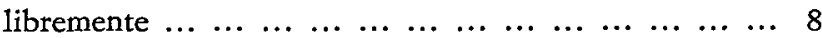

$\begin{array}{llllllllllllll}\text { Matrimonio civil } \ldots & \ldots & \ldots & \ldots & \ldots & \ldots & \ldots & \ldots & \ldots & \ldots & \ldots & \ldots & \ldots & \text { R. } 2, \text { R. } 3, \text { R. } 4\end{array}$

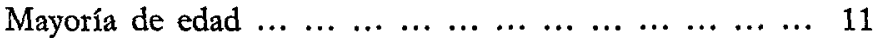

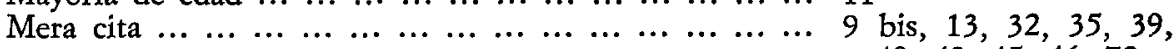

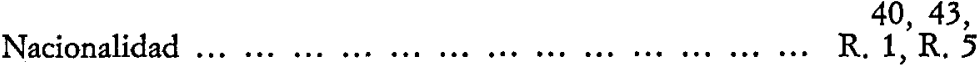

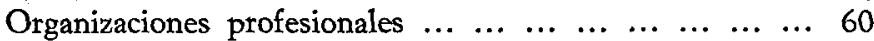

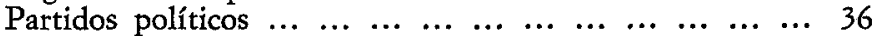

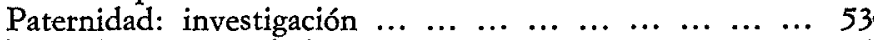

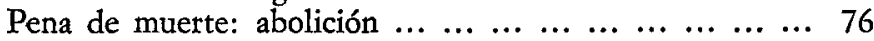

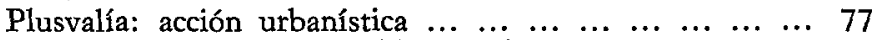

Potestad originaria de establecer tributos $\ldots \ldots \ldots \ldots . . . .25$ 
Materias

Sentencias, autos y resoluciones (se indica el número marginal de los mismos, tal y como aparecen en el Indice cronológico)

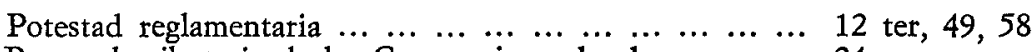

Potestad tributaria de las Corporaciones locales ... ... ... 24

Precepto penal sustantivo: el art. 24 de la Constitución

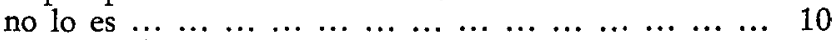

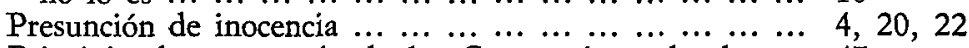

Principio de autonomía de las Corporaciones locales ... 47

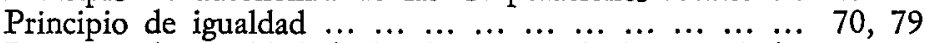

Principio de igualdad de los hijos ante la ley con inde-

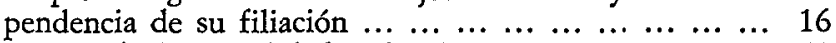

Principio de inamovilidad judicial ..................... 42

Principio de inviolabilidad e inmunidad parlamentaria $\ldots . .19$

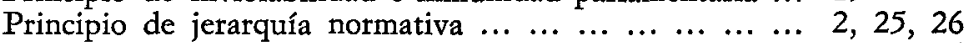

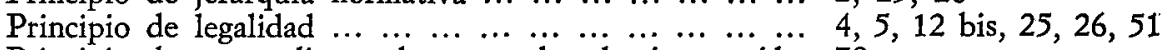

Principio de que nadie puede ser condenado sin ser oído. 78

Principio de presunción de inocencia .............. $4,20,22$

Principio de reserva de ley $\ldots \begin{array}{llllllllll} & \ldots & \ldots & \ldots & \ldots & \ldots & \ldots & \ldots & 12 & \text { ter }\end{array}$

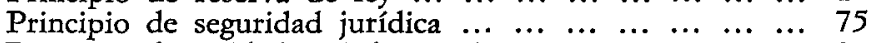

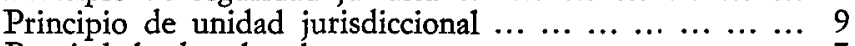

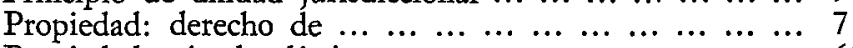

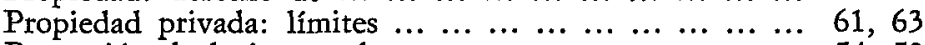

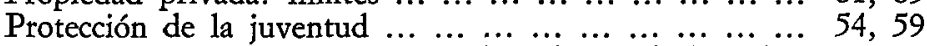

Registro de asociaciones: a los solos efectos de la publi-

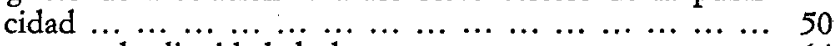

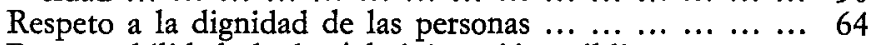

Responsabilidad de la Administración pública $\ldots \ldots \ldots \ldots 7,23$

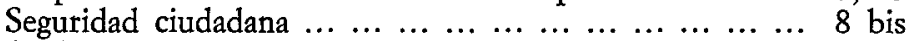

Sindicato $\ldots \begin{array}{llllllllllllllll} & \ldots & \ldots & \ldots & \ldots & \ldots & \ldots & \ldots & \ldots & \ldots & \ldots & \ldots & \ldots & \ldots & 8,52\end{array}$

Sometimiento de la Administración a los fines que la jus-

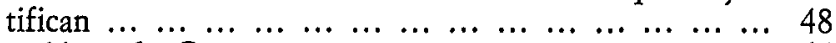

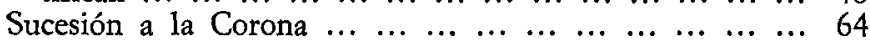

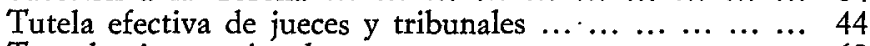

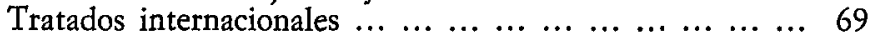

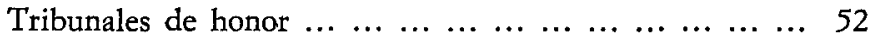

$\begin{array}{llllllllllllllll}\text { Tributos } & \ldots & \ldots & \ldots & \ldots & \ldots & \ldots & \ldots & \ldots & \ldots & \ldots & \ldots & \ldots & \ldots & \ldots & 24\end{array}$

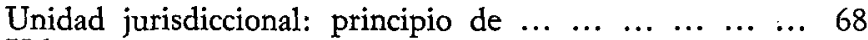

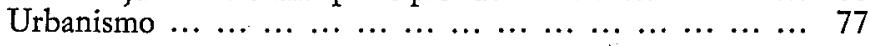




\section{REPERTORIO 1981 (CONCLUSION)}

\section{A) Sentencias $y$ autos}

Núm. 67. Sentencia de 1 de diciembre de 1981. Contencioso-Administrativo. Sala V. Ponente, F. Mateo Lage. ARTICULO 164.1 DE LA CONSTITUCION.

\section{Administración local}

Es procedente el levantamiento de la suspensión del acto de un Ayuntamiento por el gobernador civil correspondiente, en aplicación de la doctrina de la sentencia del Tribunal Constitucional de 29 de abril de 1979.

Considerando: Que por la representación de la Administración del Estado y por la de los que actuaron en primera instancia como coadyuvantes de aquélla, se impugna la sentencia dictada por la Sala de lo Contencioso-Administrativo de la Audiencia Territorial de Las Palmas por la que se acordó, en el procedimiento especial regulado en el art. 118 de la Ley de esta Jurisdicción, levantar la suspensión efectuada por el gobernador civil de la provincia, de la resolución del alcaldepresidente del Ayuntamiento de Arucas por la que se decidió que la jubilación por edad de un funcionario municipal del subgrupo de Auxiliares de Administración General habría de efectuarse a los setenta años, por ser ésta la edad aplicable con carácter general, en virtud de la interpretación que se hacía en dicha resolución del art. 38.2 del Decreto 3046/1977, de 6 de octubre, que aprobó el Texto Articulado Parcial de la Ley 41/1975, de Bases del Estatuto del Régimen Local, en relación con las Ordenes del entonces Ministerio de la Gobernación de 6 de abril de 1968 y 9 de diciembre de 1975 y con la plantilla aprobada para la Corporación.

Considerando: Que, levantada la suspensión del acto mencionado por la sentencia apelada, según se ha expresado, fundándose para ello el Tribunal que la dictó en la inexistencia de infracción manifiesta de las leyes, motivo de dicha suspensión, debe determinarse con carácter prioritario, en virtud de la obligación que tienen los órganos de esta jurisdicción de apreciar, aun de oficio, las infracciones formales en que haya podido incurrirse en la vía administrativa, si en el presente caso era condición suficiente para acordar la suspensión la concurrencia del motivo en que se apoya, previsto en el att. 362.1.4. Refundido de 24 de junio de 1955, dada la fecha de aquélla, es decir, contemplando la cuestión desde una perspectiva de carácter general, si es posible la suspensión por los gobernadores civiles de los actos locales en virtud del art. 365.1 de la Ley de Régimen Local citada en relación con el precepto de la misma antes mencionado, a partir de la vigencia de la Constitución, dado el principio general de autonomía de las Corporaciones locales proclamado en su art. 137 y reiterado en su art. 140 al garantizarlo, y ello hasta la entrada en vigor del Decreto-ley $3 / 1981$, de 16 de enero, en cuyo art. $8^{\circ}$ se regulan los supuestos de suspensión de los actos y acuerdos locales por la Administración del Estado, problema que ya ba sido resuelto por el Tribunal Constitucional en su sentencia de 29 de abril de este año, en la que se declaró, con la eficacia establecida en el art. 164.1 de la Constitución, desarrollado en el art. 38.1 de la Ley Orgánica del Tribunal, 2/1979, de 3 de octubre, al decidir una cuestión de inconstitucionalidad, que la suspensión fundada, como aqui, en el juego de los artículos citados no se ajusta a la Constitución cuando no existe otra razón que el control de legalidad, siendo únicamente posible conforme a la Constitución cuando los acuerdos «afecten a la 
competencia del Estado o excedan del limite de la competencia propia para la gestión de los intereses de la entidad local», ninguna de cuyas circunstancias es aplicable al presente caso, por lo que, babiendo sido dictados tanto el acto de cuya suspensión se trata como ésta en el periodo comprendido entre la vigencia de la Constitución y la entrada en vigor del Decreto-ley 3/1981, antes mencionado, y al que se refiere la sentencia del Tribunal Constitucional, ha de apreciarse que en este caso el gobernador civil carecía de facultades para acordar la suspensión, por lo que ba de confirmarse el levantamiento de ésta decidido por el tribunal sentenciador en primera instancia, aunque sea por otros fundamentos que el tomado en consideración por aquél, lo que resulta irrelevante a los efectos pretendidos, desestimándose los recursos de apelación enjuiciados en los que, por otra parte, se solicitaba erróneamente el mantenimiento de la suspensión efectuada por el gobernador civil, en vez de la anulación del acto objeto de aquélla, único pronunciamiento posible como alternativa al levantamiento de la repetida suspensión, según el artículo 118.5 de la Ley de esta Jurisdicción; sin que haya motivo legal para la expresa imposición de costas:

\section{Comentario}

Véase sentencia del Tribunal Constitucional de 29 de abril de 1981. Núm. 68. Auto de 3 de diciembre de 1981. Criminal. Sala II. Ponente, L. Vivas
Marzal. ARTICULO 117.5 DE LA CONSTITUCION.

Ambito estrictamente castrense

Turisdicción militar

Unidad jurisdiccional

\section{Antecedentes}

Autos de 2 de mayo de 1980 (núm. 3 del Repertorio de 1980), de 26 de septiembre de 1980 (núm. 16 del Repertorio de 1980), de 14 de octubre de 1980 (núm. 24 del Repertorio de 1980) 31 de octubre de 1980 (núm. 29 del Repertorio de 1980) y 27 de marzo de 1981 (núm. 9 del Repertorio de 1981).

Considerando: Que, con anterioridad a la vigencia de la Constitución de 1978, el Código de Justicia Militar de 1945 atribuia la competencia a los tribunales militares atendiendo a tres criterios fundamentales, esto es, por razón del delito, por razón del lugar y por razón de las personas, lo que determinaba, en ocasiones, una expansión singular de dicha jurisdicción; la cual no sólo podía enjuiciar a los no aforados por la perpetración de delitos militares, sino conocer, con algunas excepciones, de delitos comunes perpetrados por militares o cometidos en lugar reputado castrense. Sin embargo, la Constitución de 1978, siguiendo el influjo de doctrinas que ya se manifestaron en el siglo XIX y que son propias de Estados gobernados por regímenes políticos liberales y democráticos; en el núm. 5 de su art. 117, por una parte, proclamó el principio de unidad jurisdiccional como base de la organización y funcionamiento de los tribunales, y, por otra, reconociendo implícitamente la necesidad de la existencia de un C. P. Militar -justificado por la disciplina y la subordinación que constituyen la espina dorsal de los ejércitos- y la legitimidad de los tribunales de este orden, circunscribió o redujo el ámbito de su competencia a lo «estrictamente castrense» y a la situación de estado de sitio, anunciando programáticamente que la «Ley regulará el ejercicio de la jurisdicción militar» en el ámbito dicho; cuya Ley ba sido la Orgánica de 6 de noviembre de 1980, 
la cual ha reformado el Código de Justicia Militar siguiendo la pauta constitucional y restringiendo la competencia de los tribunales militares, los cuales, en líneas generales, conocen de los delitos militares, pero quedando sumamente reducida, aunque no suprimida, dicha competencia por razón del lugar y por razón de la persona.

ConsIDERANDO: Que si se procede a un examen aislado y asistemático del número 2 del art. 7 del Código de Justicia Militar, redactado conforme a la reforma aludida, y se atiende exclusivamente a una interpretación puramente gramatical del mismo, llegaríase fácilmente a la conclusión de que el conocimiento de las faltas comunes cometidas por militares correspondería de ordinario a los tribunales de dicho orden, y sólo excepcional y residualmente, y siempre y cuando dichas faltas no afectaren al buen régimen de los ejércitos o al decoro de sus clases, la autoridad judicial militar se inhibirá en favor de la ordinaria; interpretación esta que conduciría: a) a una preeminencia o prerrogativa de la jurisdicción militar, la cual, a su arbitrio y siempre que lo considerara conveniente, conocería de las faltas comunes perpetradas por militares; b) a una situación de inferioridad de la jurisdicción ordinaria, la que sólo residualmente, como ya se ha dicho, y de modo excepcional, enjuiciaría las indicadas faltas, y c) a un monopolio interpretativo o exclusiva facultad de la autoridad judicial militar en orden a la determinación de cuándo afecta la falta al buen régimen de los ejércitos o al decoro de sus clases, quedando, por consiguiente, confiada únicamente a su criterio la cuestión de la fijación de la jurisdicción competente, sin que la ordinaria o esta sala de conflictos tuvieran atribución alguna al respecto.

ConSIDERANDO: Que esto no obstante, si el precepto debatido, siguiendo las normas de hermenéutica contenidas en el art. 3.1 del Código Civil -y que son de aplicación general-, se concatena con el núm. 1 del art. 16 del Código de Justicia Militar vigente -cuyo texto atribuye al conocimiento de la jurisdicción ordinaria «los delitos que tengan naturaleza común, cometidos por militares, cuando los hechos no afectaran al buen orden y servicio de las fuerzas armadas»- y se conecta con la raíz constitucional que se reseñó anteriormente, y se tiene en cuenta, además, el espíritu y la finalidad de la reforma y el entorno social en el que se ha de aplicar, se llega, fácil, inevitablemente y de modo certero, a la conclusión, basada en principios interpretativos lógicos, sistemáticos, históricos, sociológicos $\mathrm{y}$ teleológicos, de que el legislador, y sobre todo la propia ley, lo que han querido decir es que la jurisdicción ordinaria, en lo que concierne a los delitos o faltas comunes cometidos por militares, es la preponderante, y la militar, la residual, y no al contrario, siempre y cuando, naturalmente, que se trata de infracciones comunes cometidas por militares que no afecten al buen orden y servicio de las fuerzas armadas o al decoro de sus clases; solución esta que es y ha de ser uniforme a menos que se incurriera en atsurda decisión diferenciativa, discriminadora de una y otra clase de infracciones punibles, comportando la teferida solución que, surgida discrepancia o contienda, positiva o negativa, entre ambas jurisdicciones sobre la incidencia de la falta o del delito en el servicio o en el buen régimen de las fuerzas armadas o en el decoro de sus clases, ninguna de ellas prevalezca por su sola autoridad ni se halle en situación de decidir omnímodamente y sin posibilidad de impugnación o de objeción, y que sea esta Sala de Conflictos, de la que torma parte un excelentísimo señor vocal militar, la que pueda y deba dirimir la cuestión o conflicto planteado, examinando soberanamente el problema de la mentada incidencia que tanto relieve tiene a la hora de resolver el susodicho conflicto.

Considerando: Que en el caso entablado, a los solos efectos de la adecuada resolución de esta contienda, lo sucedido fue, brevemente expuesto, que el 22 de diciembre de 1980, y en el Paseo de Colón de Pontevedra, un automóvil conducido por un paisano, hallándose detenido ante un semáforo, fue embestido, por detrás, por un «Land Rover» al servicio de la Comandancia de Marina de Villa- 
garcia de Arosa y conducido por un marinero, causándole desperfectos en el vehículo civil justipreciados en 14.073 pesetas. $Y$ constituyendo tales hechos una falta culposa de daños prevista en el art. 600 del Código penal, perpetrada por un aforado, la competencia para conocer de la misma corresponde a la jurisdicción ordinaria, y ello no sólo por la falacia del principio de minima non curat pretor, sino porque las autoridades judiciales de Marina no han explicado suficientemente - limitándose a glosar y parafrasear el texto del núm. 1 del art. 7 del Código de Justicia Militar pero sin aportar datos concretos y demostrativos- de qué modo un hecho culposo intrascendente, muy frecuente, y concerniente a la circulación rodada, urbana o interurbana, puede incidir en el buen orden de los ejércitos o en el decoro de sus clases, y porque esta Sala, que percibiría dicha trascendencia y relevancia de tratarse de maniobras militares, de ejercicios tácticos, de columnas motorizadas castrenses en marcha o de otro supuesto análogo o similar, no la aprecia en un habitual incidente de tránsito carente de especial gravedad o de singularidad funcional respecto a la eficacia y buen orden de las fuerzas armadas; procediendo, a la vista de lo razonado, decidir el presente conflicto jurisdiccional positivo entablado entre el señor juez de distrito núm. 2 de Pontevedra y el excelentísimo señor capitán general de la Zona Marítima del Cantábrico a favor del primero, a quien con testimonio de este auto se remitirá lo actuado, participándose lo resuelto a la excelentísima autoridad de Marina implicada en el conflicto.

Núm. 69. Sentencia de 3 de diciembre de 1981. Contencioso-Administrativo. Sala III. Ponente, J. L. Ruiz Sánchez. ARTICULO 96 DE LA CONSTITUCION.

Convenios internacionales

Tratados internacionales

Las notas verbales no son un sistema irregular, sino uno de los medios para llamar la atención a otro Estado para la observación del principio pacta sunt servanda.

Considerando: Que por el Consejo General de Colegios de Ingenieros Industriales, a través de su representación legal, se impugna el Real Decreto 1610/1979, de 4 de abril, por el que se reconocen efectos civiles a los estudios de la Facultad de Derecho, de la Facultad de Ciencias Económicas y Empresariales (Sección Empresariales), de la Escuela Técnica Superior de Ingenieros Industriales y de la Escuela Universitaria de Ingeniería Técnica Industrial de la Universidad Pontificia de Comillas, con sede en Madrid, pero para comprender el alcance de esa impugnación y la posibilidad o no de su prosperabilidad es preciso establecer las circunstancias y argumentos que se exponen por las partes intervinientes, como demandante y codemandados, y así hemos de señalar que la parte actora invoca comọ alegaciones que refrendan su tesis las siguientes: a) Omisión de los trámites establecidos por los arts. 129 y 130 de la Ley de Procedimiento Administrativo, que conduce a la nulidad objeto de previsión en el $47.1, c$ ) de la referida Ley, pretensión que proyecta en orden a la ausencia de firma que autorizase «la nota verbal» de la Nunciatura Apostólica, como expresión generatriz del acto que se combate, y además se prescindió asimismo del informe del Colegio interesado; $b$ ) $\mathrm{Si}$ el $\mathrm{De}$ creto impugnado no se conceptuara como «norma» y sí como «acto resolutorio», la nulidad vendría determinada por aplicación del art. 30 de la Ley de Régimen Jurídico de la Administración del Estado, y c) En cuanto el Real Decreto combatido no cumple con el condicionamiento establecido en el Convenio de 5 de abril de 1962 concertado entre la Santa Sede y el Gobierno español, ratificado por Instrumento de 10 de mayo del mismo año, la conclusión a que debe llegarse 
también es de nulidad; exponiéndose por los codemandados, el abogado del Estado, en nombre y representación de la Administración General del Estado, y por la Compañía de Jesús -que rige el Instituto Católico de Artes e Industrias de Madrid- y la Universidad Pontificia de Comillas, el obstáculo de orden formal, como el deducible de la falta de legitimación, invocada al amparo del art. 82.b) en relación con el 28.a) de la Ley Reguladora de esta Jurisdicción y art. $30^{\circ}, 1 . a$ ) del Decreto 1932/1969, de 24 de julio, regulador del Consejo General de Colegios Oficiales de Ingenieros Industriales, para de modo esencial centrar el tema en la limitada facultad impugnativa del órgano atacante, en cuanto a su representatividad natural, ya que el ámbito del Real Decreto en liza se refiere a estudios realizados en la Facultad de Derecho y Ciencias Económicas (Sección de Empresariales), además de los de la Escuela Universitaria de Ingeniería Técnica Industrial; peto también se exponen otros argumentos que, en el aspecto sustantivo, tratan de desvirtuar la pretensión deducida, los que toman como fundamento la imposibilidad de infringir las normas referentes a la elaboración de las disposiciones de carácter general, en cuanto asignan al Real Decreto combatido el valor de simple acto resolutorio administrativo, pero aun en el supuesto contrario, las consecuencias deducibles no adquieren el dramatismo que le trata de imprimir la parte actora.

Considerando: Que examinando la causa invocada, como falta de legitimación, en cuanto que el interés de la entidad actora es limitado, ya que el Real Decreto tiene una amplitud o extensión superior a las funciones representacionales que le son conferidas por la norma, pues afecta al reconocimiento de efectos civiles de los estudios cursados a otras manifestaciones del conocimiento humano de aquellos que patrocina la parte recurrente, hemos de tener presente que la posibilidad impugnatoria viene derivada por el interés directo que tal organismo tiene, en función de la actividad y protección que dispensa a unos concretos profesionales, y en este orden, no podemos olvidar el contenido y finalidad perseguida por el Real Decreto sometido a la acción jurisdiccional, de modo que en su compacidad constituye una unidad que ofrece ciertas dificultades para su escindibilidad, en función a lo que constituye su objetivo, destinatarios directos e indirectos de la misma, porque no sólo tiene un aspecto de clara positivación en su objetivo - reconocimiento de efectos civiles de ciertos estudios cursados en una institución concreta no estatal-, sino que comporta para otros una expresión de orden negativo, como nos lo revela el hecho mismo de la oposición formalizada por un conjunto de personas a quienes, en definitiva, representa el Consejo de Colegios de Ingenieros Industriales, por lo que hemos de sentar la consecuencia de que dicho ente se encuentra legitimado para combatir el Real Decreto de referencia, aun cuando aparentemente pueda existir desproporción entre el petitum y su interés, ya que se ha puesto de manifiesto las peculiaridades que singularizan el acuerdo atacado, máxime cuando se reconoce, de forma paladina, un cierto interés en orden a su impugnación, lo que le habilita plenamente para ello, por lo que procede la desestimación de la causa de inadmisibilidad alegada.

CONSIDERANDO: Que se arguye como irregular la «nota verbal» dirigida por la Nunciatura Apostólica al Ministerio de Asuntos Exteriores, interesando la efectividad del Convenio entre la Santa Sede y el Estado español de 5 de abril de 1962, concertado en aplicación del párr. $20^{\circ}$ del art. 31 del Concordato de 27 de agosto de 1953, consecuencia carente de rigor en el ámbito del Derecho internacional, puesto que en las relaciones entre Estados puede acudirse a formas simplificadas como medios de expresar la voluntad y pretender el cumplimiento de los acuerdos concertados, constituyendo no obstante su simplificación, manifestaciones que entran en el ámbito de los usos y costumbres internacionales con plena virtualidad y eficacia, como formas que pueden alcanzar la efectividad de protección y realidad en la ejecución de los acuerdos o de una actividad desarrollada, con un fin espe- 
cífico dentro del ámbito del Derecho internacional -art. 96 de la Constitución española de 1978-, como uno de los medios de llamar la atención a otro Estado, para la observancia del principio «pacta sunt servanda»; no olvidemos, por otro lado, que el art. 26 del Convenio de Viena ya establecía que «todo tratado obliga a las partes y debe ser cumplido por ellas de buena fen, y la Santa Sede, a través de su representación diplomática -Nunciatura Apostólica- ba instado el cumplimiento de lo estipulado en el Convenio suscrito entre las partes de la forma más simplificada y sensible que la práctica internacional admite: nota verbal.

Considerando: Que cuestionada la naturaleza del Real Decreto impugnado, de modo especialmente enfatizado por las partes, en cuanto a la problemática suscitada en torno a la observancia o no de las normas contenidas en el título VI, capítulo I, de la Ley de Procedimiento Administrativo, hemos de proceder a examinar, de modo objetivo, el contenido del mismo y su estructura, como presupuestos que han de contribuir a discernir el problema planteado, y así, hemos de destacar que el referido Real Decreto, a su denominación específica, le sigue una breve exposición de las razones de su promulgación, con referencia al informe favorable del órgano consultivo adecuado - Comisión Permanente de la Junta Nacional de Universidades-, departamento ministerial proponente al Consejo de Ministros, y su aprobación, previa deliberación del mismo, procediendo in continenti y bajo la forma ad sollemnitatem «Dispongo» a la redacción de los tres artículos que le integran: el primero, referido al objeto específico, representado por el explícito reconocimiento de efectos civiles a los estudios concretos que constituye el tema del Decreto, con observancia del régimen previsto en el art. $60^{\circ}$ del Convenio entre la Santa Sede y el Estado español de 5 de abril de 1962; el segundo, que es una disposición derogatoria en su doble aspecto concreto en cuanto deja sin efecto los Decretos de 10 de agosto de 1950 y el 1559/1967, de 6 de julio, y abstracta, ya que la efectividad derogatoria alcanza o se extiende también a cuantas disposiciones se opongan a lo que se contiene en dicho Real Decreto; y un tercer artículo, que encierra una facultad de ordenación delegada, en beneficio del Departamento proponente, «para dictar cuantas disposiciones sean necesarias para la aplicación del presente Real Decreto", que alcanzó ese rango normativo, como derivación de lo prevenido en el art. 10.17 de la Ley de Régimen Jurídico de la Administración del Estado.

ConsiderANDO: Que la actividad desarrollada por la Administración, cristalizada en el Real Decreto que se cuestiona, por lo que hemos anticipado en cuanto a su contenido y pluralidad de personas destinatarios del mismo, como sujetos activos y pasivos, estructura, finalidad, etc., no se puede conceptuar como la simple declaración de voluntad, de juicio, de conocimiento o de deseo realizada por la Administración en el ejercicio de una potestad administrativa, distinta de la potestad reglamentaria, sino que se trata del acto de voluntad encaminado a dar efectividad y cumplimiento, en el ámbito de la soberanía nacional - territorio-, de unas consecuencias, aún no establecidas, respecto a los efectos civiles de futuro que había de tener una serie de estudios que, en virtud de normativa específica y convenida, venían realizándose, y por ello cuando se procede al análisis de los elementos integrantes del concepto del acto administrativo, así como de los presupuestos subjetivos como objetivos que le dan vida, con las derivadas del actuar reflejado en el Real Decreto combatido, se deduce que éste, como expresión de una consecuencia querida y convenida por dos Estados soberanos, cuyas respectivas manifestaciones en orden a la virtualidad interna de tales acuerdos han seguido el trámite adecuado, la forma de exteriorización no puede, por su contenido y manifestación intencional de propósitos y vinculación futura, ser calificado como un simple acto de la Administración como generador de una situación jurídica con un solo y único destinatario directo e inmediato -Universidad de Comillas-, cuando es plasmación de unos efectos de naturaleza especial que, estando depo- 
sitados en los órganos administrativos de la docencia pública, el Estado se desprende de los mismos $\mathrm{y}$, en virtud de acuerdos concertados, en el ámbito del Derecho internacional, se reconoce, con un desprendimiento parcial de esa facultad, efectos civiles a estudios cursados en instituciones no estatales, y no se puede afirmar que el simple reconocimiento de esos efectos civiles cierre todas las posibilidades y consecuencias deducibles, sino que, por el contrario, se abre una serie o gama de cuestiones a contemplar que plantea una problemática en cuanto a las consecuencias de esos «efectos civiles» que han de ser objeto de previsión futura, de ahí la «delegación normativa» - potestad reglamentaria- que se asigna al departamento ministerial proponente en el art. 3. $\mathrm{del}$ Real Decreto que se combate.

Considerando: Que abundando en lo expuesto, el examen de la normativa que ha tenido realidad en nuestro ordenamiento en orden a los estudios de ingeniería cursada en el Instituto Católico de Artes e Industrias de Madrid -ICAI-, fundamentalmente a partir del Decreto de 10 de agosto de 1950 , con sus diversas vicisitudes y fases de actuación, estudios y control por la Universidad Complutense, y la pretensión de la Santa Sede, cristalizada en la «nota verbal» elaborada por la Nunciatura Apostólica, implica la actividad encaminada a consumar la plena virtualidad de los estudios impartidos, autorizados y cursados a través de la Universidad Pontificia de Comillas, con sede en Madrid, que no habían llegado a la culminación de sus efectos, tal y como fue realmente querido por las partes firmantes del Convenio de 5 de abril de 1962, suscrito en aplicación del párr. 2. ${ }^{\circ}$ del art. XXXI del Concordato de 27 de agosto de 1953, y si, en definitiva, el Real Decreto 1610/ 1979 es el reconocimiento explícito y terminante de los efectos civiles de los estudios a que el mismo se refiere, como derivación del Convenio, su eficacia dentro del territorio nacional como acto de soberanía, tiene que tener expresión a través de un acto que, con el debido rango normativo, exteriorice la realidad y alcance del compromiso contraído por el Estado español y los efectos vinculantes que comporta erga omnes, puesto que si no se puede admitir la singularización del sujeto activo, como hemos razonado, menos aún en lo que al sujeto pasivo se refiere, pues comporta un mandato dirigido a todos los súbditos españoles, que no sólo tienen la obligación de aceptar y reconocer los efectos civiles de los estudios no estatales, a que se refiere el Real Decreto, llevados a efecto por las facultades y escuelas integradas en la Universidad Pontificia de Comillas, como aspecto estático de la disposición dirigida a los mismos, sino que tiene un aspecto dinámico, representado por la cláusula derogatoria y por la «delegación normativa», como causa de donde deriven las disposiciones que se dicten y sean necesarias para su aplicación, aunque, por otro lado, la naturaleza que asignamos al Real Decreto atacado se desvirtúe al exigir unos condicionantes para su aplicación como acto-condición, porque la efectividad y exigibilidad de unos presupuestos determinados no es más que consecuencia de lo concertado con el Convenio suscrito, que ha de tener traslación, en su cumplimiento, como requisitos previstos en el mismo, y que su proyección de futuro, en orden a las previsiones omisivas, representa una faceta a contemplar en la «delegación normativa» contenida por el art. 3..$^{\circ}$ del Real Decreto que se impugna, pero que no admite, y menos aún desvirtúa su naturaleza, asignándole la de un simple «acto-condición».

ConsiderANDO: Que lo consignado y la plasmación o cristalización de los efectos civiles, en cuanto a los estudios cursados en la Universidad Pontificia de Comillas, no es más que la consecuencia final alcanzada a través de todo el conjunto de disposiciones que han ido regulando el asentamiento, instalación, desenvolvimiento, régimen de estudios y disciplinario, pero que no empece a la naturaleza intrínseca del Real Decreto que se impugna y a la normativa aplicable para su elaboración, lo cual nos conduce a examinar aquellos argumentos que se articulan como representativos de supuestas infracciones de procedimiento, por inadaptación a lo 
prevenido en los arts. 129 y 130 de la Ley de Procedimiento Administrativo, y aquellos otros argumentos que centra la inviabilidad del Real Decreto en el incumplimiento de lo prevenido en el art. 5.० del Convenio de 5 de abril de 1962.

Considerando: Que entrando en el estudio de las causas de oposición articuladas, la invocación in abstracto de la inobservancia del procedimiento carece de rigor en su efectividad, ya que es constante la orientación doctrinal establecida por esta Sala en dicho sentido, pero es preciso destacar que se acusa de modo concreto la omisión del informe previo del organismo recurrente, a tenor de lo prevenido en el art. 130.4, así como la falta de causa justificativa respecto a la promulgación del Real Decreto combatido al rechazar eficacia estimulante a la «nota verbal», como forma simplificada de comunicación entre los Estados, en el ámbito del Derecho internacional, para instar la efectividad de las relaciones derivadas de la comunidad internacional $y$, de modo particular, entre partes relacionadas entre sí en virtud de situaciones o relaciones jurídicas, hemos de poner de relieve que la «nota verbal» cursada por los trámites diplomáticos conducentes, Ministerio de Asuntos Exteriores, constituyó el dispositivo inicial para la elaboración del proyecto del Real Decreto contradicho, evacuando informe preceptivo, no vinculante, la Comisión Permanente de la Junta Nacional de Universidades, que era favorable a su aprobación, que se llevó a efecto por el Consejo de Ministros, previa deliberación del mismo, si bien por la acusada omisión del informe por el órgano corporativo afectado no pueden extraerse las consecuencias que se establecen por la parte recurrente, porque este informe participa de una doble cualidad: su posibilidad y oportunidad, de acuerdo con lo que previene el art. 130.4 de la Ley de Procedimiento Administrativo.

Considerando: Que la consecuencia que hemos de deducir de lo consignado está en poner de manifiesto la observancia de las normas en orden a la elaboración de las disposiciones de carácter general, porque si bien se observan algunas deficiencias, acusadas in genere por la parte recurrente, independientemente de las señaladas con carácter concreto y ya examinadas sin que la falta de la concreción tenga la consecuencia que se pretende por el recurrente, máxime cuando ya hemos indicado la necesidad de especificar los trámites que se estimen infringidos al objeto de valorar sus consecuencias y efectos en orden a la posible nulidad invocada, puesto que no todas ellas son susceptibles de provocar el resultado que se postula, de donde es preciso sentar la conclusión desestimatoria del recurso contencioso interpuesto por la parte recurrente, sin que proceda asimismo acceder a la variante que se apunta por la representación de los codemandados particulares, en cuanto que su posibilidad de acceder a ello no tiene cabida en el ámbito y concepción del Real Decreto 1610/1979, cuya legalidad es cuestionada.

Consrderando: Que no procede apreciar la existencia de causas o motivos suficientes para hacer especial imposición, en cuanto a las costas causadas en este recurso, de conformidad con lo prevenido en el art. 131.1 de la Ley Reguladora de esta Jurisdicción, a parte alguna determinada.

Núm. 70. Sentencia de 4 de diciembre de 1981. Contencioso-Administrativo. Sala V. Ponente, J. Diaz de Lope-Díaz y López. ARTICULO 14 DE LA CONSTitución.

\section{Principio de igualdad}

Se inftinge el principio de igualdad aplicando a los funcionarios de la misma escala distintos incentivos económicos.

Considerando: Que en virtud de las sentencias de 26 y 28 de septiembre de 1977, dictadas por esta Sala, se asignó a los funcionarios del Instituto Nacional 
de Reforma y Desarrollo Agrario, en adelante abreviadamente IRYDA, que prestaba servicio en las Escalas de Veterinarios y Letrados, el coeficiente retributivo 5 en vez del 4 que tenían asignado, reconociéndoles el derecho a que se les liquidaran y abonaran los atrasos que por tal concepto les correspondían a partir de 1 de enero de 1973, habiendo acordado la Administración el cumplimiento de tales sentencias por medio del Decreto 2080, de 15 de julio de 1978, en el que señaló el coeficiente 5 a todos los funcionarios que formaban las plantillas de veterinarios y letrados del IRYDA, hubieran sido o no recurrentes en los pleitos que originaron las sentencias de 26 y 28 de septiembre de 1977, planteándose en el presente recurso la cuestión relativa a si los efectos de la aplicación de las sentencias citadas deberá retrotraerse para los litigantes en este pleito que no fueron parte en aquéllas al 1 de enero de 1973, como declararon las repetidas sentencias y pretenden en el suplico de la demanda, o bien no procede abonarles cantidad alguna en concepto de atrasos, por no haber sido recurrentes en aquellos dos pleitos, como decidió el Consejo de Ministros en el Acuerdo, objeto del presente recurso, de 15 de julio de 1978.

ConsIDERANDo: Que de conformidad con lo dispuesto en el art. 86.2 de la Ley Jurisdiccional, las sentencias que anulen el acto o la disposición recurridos producen efecto no sólo entre las partes, sino también respecto de las personas afectadas por los mismos, de cuyo precepto se desprende el poder expansivo de las sentencias anulatorias en los procesos contencioso-administrativos, mediante el cual extienden sus efectos a terceros que se encuentran, respecto al acto o disposición anulados, en idéntica situación que los recurrentes, amparando, por tanto, intereses legítimos situados fuera del área del litigio, según declaró la sentencia de 21 de abril de 1961, reiterada por las de 22 de septiembre de 1967 y las que en ella se citan, 16 de junio de 1969,25 de junio de 1971 y 26 de enero de 1973, habiendo expresado la de 23 de marzo de 1979 que la sentencia produce efectos generales erga omnes y, por tanto, el pronunciamiento de la misma es vinculante para los afectados por dicha resolución, de cuyo principio se deduce la ampliación de los límites subjetivos del anterior pronunciamiento a quienes sin haber sido parte en el proceso en que se dictó se encuentren afectados por los actos recurridos, de tal manera que puedan acogerse a los efectos favorables del mismo y en igual forma a como se resuelve en la expresada sentencia respecto a los que allí litigaron.

Considerando: Que admitiendo la Administración esta doctrina, no accede a las pretensiones de los aquí recurrentes por estimar que el asunto está prejuzgado negativamente por una de las dos sentencias que se ejecuta, la de 28 de septiembre de 1977, relativa a los letrados, al expresar en uno de sus considerandos «que la eficacia positiva de cosa juzgada de las sentencias contencioso-administrativas anulatorias del acto o disposición recurridos declarada en el art. 86.2 de la Ley Reguladora no comprende al reconocimiento del derecho judisdiccional individualizado pretendido por los litigantes, como consecuencia de aquella previa anulación que no es dable a quienes no han sido parte en el proceso, alterando los límites subjetivos de éste...».

CoNSIDERANDO: Que este razonamiento, que no está recogido en la sentencia de 26 de septiembre de 1977, sobre los veterinarios, no tiene la trascendencia negativa que le confiere la Administración, sino que su significado es el de que no procedía pronunciarse en la sentencia sobre la situación jurídica individualizada de quien no había sido parte en el pleito, afirmación acorde con los límites subjetivos del proceso en virtud de los cuales sólo puede ventilarse con las partes intervinientes en el mismo, pero que no cercena los efectos erga omnes de la sentencia anulatoria, pues como declaró la sentencia de esta Sala de 16 de junio de 1969, «tal efecto no se extiende directamente al reconocimiento de las situaciones jurídicas individualizadas de los que no fueron parte en el proceso, las que deberán ser 
objeto de atención por la Administración al llevar a puro y debido efecto la sentencia, adoptando las medidas adecuadas a la respectiva situación de los demás afectados por la anulación, que si no obtienen de oficio o a su instancia el reconocimiento procedente como consecuencia del fallo, podrán interponer otros procesos, previa solicitud de la extensión a su favor de lo resuelto jurisdiccionalmente», siendo éste el sentido que hay que darle al razonamiento de la sentencia de 28 de septiembre de 1977 y en ningún supuesto el de estimar que en ella se resolvía para el futuro sobre los derechos de los que no habiendo sido litigantes en el pleito resultaban afectados por la sentencia dictada en el mismo.

CONSIDERANDO: Que en virtud de lo expuesto, es procedente aplicar a los recurrentes en este pleito los pronunciamientos de las sentencias de 26 y 28 de septiembre de 1977, reconociéndoles el derecho al abono de atrasos motivados por el cambio de coeficiente, con efectos de 1 de septiembre de 1973, como establecieron las resoluciones judiciales citadas, porque se encuentran en la misma situación que los que fueron litigantes en aquellas sentencias y los pronunciamientos de éstas les afectan directamente.

Considerando: Que el Acuerdo del Consejo de Ministros de 8 de julio de 1978 , objeto de este recurso, establece en el apartado $20^{\circ}$ que a partir de 1 de enero de 1978, los letrados y veterinarios quedan equiparados en cuanto a incentivos a los ingenieros y arquitectos del organismo, ya que constituyen una única escala, y en el apartado $50^{\circ}$ del propio Acuerdo expresa que los acuerdos anteriores - entre ellos está el apartado $20^{\circ}$ - se refieren exclusivamente a los funcionarios recurrentes en los procesos que dieron lugar a las sentencias de 26 y 28 de septiembre de 1977, en cuya ejecución se dictaba el Acuerdo; esta referencia viene a desvirtuar la pretendida inadmisibilidad del recurso por falta de acto administrativo recurrible, en cuanto a la reclamación de incentivos, aducida por la Administración al resolver el 31 de julio de 1980 el recurso de reposición, aunque esta causa de inadmisibilidad no fue alegada por el abogado del Estado al contestar la demanda.

ConsIDERANDO: Que la retribución por el concepto de incentivos, que también es objeto del presente recurso, les ha sido aplicada a los litigantes en este pleito, con efectividad de 1 de septiembre de 1978, fecha de la publicación del Decreto de modificación de coeficientes, de conformidad con lo resuelto por el Acuerdo del Consejo de Ministros impugnado en este recurso, en cambio a los funcionarios que fueron parte en los recursos contencioso-administrativo en los que se dictaron las sentencias cuya efectividad se pide en el presente proceso, les fue aplicado el nuevo incentivo con efecto de 1 de enero de 1978, con evidente sentido discriminatorio entre funcionarios de una misma escala que no tiene justificación y que infringe el principio de uniformidad retributiva, expresamente establecido en la disposición transitoria $1 .^{\text {a }}$ de la Ley 35/1971, de 21 de julio, que crea el IRYDA, e infringe igualmente el principio de igualdad consagrado en el art. 14 de la Constitución, lo que obliga a estimar la pretensión formulada sobre este particular en la demanda.

CONSIDERANDO: Que en virtud de lo expuesto es procedente la estimación del recurso con la anulación de los Acuerdos recurridos, por no ser conformes a derecho, en cuanto niegan a los recurrentes el abono de los atrasos correspondientes a la modificación del coeficiente retributivo y señalan la aplicación del nuevo incentivo desde 1 de septiembre de 1978, siendo lo procedente declarar el derecho de los demandantes a la liquidación y abono de atrasos desde 1 de enero de 1973, correspondiente al período de prestación de servicios, y aplicarles el incentivo asignado a sus escalas, con efectividad de 1 de enero de 1978.

ConsIDERANDO: Que no se aprecia temeridad ni mala fe a efectos de condena en costas. 
Núm. 71. Sentencia de 5 de diciembre de 1981. Criminal. Sala II. Ponente, L. Vivas Marzal. ARTICULO 20 DE LA CONSTITUCION.

\section{Libertad de expresión}

La pornografía no está amparada por la libertad de expresión.

\section{Antecedentes}

Sentencia núm. 59 del Repertorio de sentencias de 1981.

Considerando: Que ha declarado reiteradamente este Tribunal que en supuestos como los de autos, el ejemplar de la revista o publicación de que se trate, unido a la causa, ante la imposibilidad de reproducir íntegramente su texto en la narración histórica de la sentencia de instancia, se reputa y considera no sólo complemento de dicha narración, sino parte integrante de la misma que es preciso tomar como punto de partida para la adecuada resolución de un recurso sustentado en el núm. 1..$^{\circ}$ del art. 849 de la Ley de Enjuiciamiento Criminal. Y esto sentado, basta examinar, como desagradable tarea, el ejemplar de la revista «C.» unido a autos, para comprobar, con la muda elocuencia que de él emana, que se trata de una publicación de la peor especie, en la que con un in crescendo constante de soez y pedestre salacidad, se rinde culto a una desenfrenada, desviada y aberrante sexualidad, dañosa y malsana no sólo para menores, sino para todos: en efecto, al habitual desfile de fotografías de mujeres desnudas, en actitudes desvergonzadas, incitantes y procaces, sin recatar partes pudendas ni vello pubiano, se añade ahora la visión impúdica de desnudos masculinos con exhibición de escroto y pene, la práctica, entre una pareja, de toda clase de actos sexuales, entre los que no se escatiman las variadas posturas, los actos de sodomía ni los contactos buco-genitales, las narraciones cortas o historias breves plenas de lubricidad y de mal gusto, donde se relatan hazañas eróticas no exentas de manifestaciones de masoquismo, furor uterino, poderío o potencia sexual desorbitado e increíble. transexualismo, intercambio de parejas, promiscuidad, bingo sexual y toda clase de aberraciones, y finalmente, una sección denominada «C. Conection», para heterosexuales y para bisexuales, verdadero paradigma de tercería o alcahuetería periodística perfectamente enclavable en el art. 452 bis, a), del Código penal, aunque no lo haya entendido así la Audiencia de origen. $Y$ ante este contenido indiscutiblemente obsceno, $y$ ante la ausencia de toda pretensión artística, científica o literaria que no sea la de incitar, estéril, artificial e imaginativamente a la lascivia, apartando a los lectores de la sana y normal sexualidad, que es lo que constituye la clave o esencia de la pornografía, incardinada, desde siempre, por este Tribunal, en el art. 431 del Código penal, son inválidos los babituales argumentos exculpatorios, expuestos tercamente, es decir, la evolución de las costumbres bacia cotas de mayor permisividad, la relatividad del concepto de pornografía, el destino de la revista de autos a mayores de dieciocho años, el tributo que tales publicaciones suponen a la cultura y a la civilización modernas, la libertad de expresión proclamada en la Constitución, y otros ya rechazados razonadamente por esta Sala en numerosas ocasiones y que es ocioso repetir; sin que el invocado Decreto de 16 de diciembre de 1977 -pretendida tabla de salvación de los mercenarios de este nefando tráfico- tenga más alcance que el propiamente administrativo, como también ha declarado este Tribunal, careciendo, por lo demás, de rango y eficacia para derogar un cuerpo legal fundamental como lo es el Código penal. Procediendo, a virtud de todo lo expuesto, la desestimación del primer motivo del presente recurso, basado en el núm. 1. ${ }^{\circ}$ del art. 849 de la Ley de Enjuiciamiento Criminal, por 
indebida aplicación del art. 431 del Código penal en relación con el art: 1, ap. d), del Decreto de 16 de diciembre de 1977 del Ministerio de Cultura.

CoNSIDERANDO: Que la pena de inhabilitación especial, que figura en la escala general de penas establecida en el art. 27 del Código penal, es una sanción privativa de derechos, que no actúa nunca como accesoria sino como principal, y cuyo alcance se determina a veces por el precepto concreto que la impone - verbigracia, artículo 417 de dicho Código-, y otras, cuando guarda silencio la parte especial del referido Código, por lo dispuesto en los arts. 36, 37 y 41 de dicho Código, no siendo lícito, por consiguiente, a los tribunales imponer la mentada pena de modo genérico y sin especificación de su alcance y de los efectos concretos que deba producir; pudiéndose añadir que, tratándose de inhabilitación para profesión $u$ oficio, el temporalmente vedado o proscrito debe ser aquel, determinado y concreto, en cuyo ejercicio se cometió el delito o, en su caso, el más íntimamente relacionado con el mismo, debiéndose abstener dichos tribunales, y como ya se ha dicho, de declaraciones genéricas, vagas e indeterminadas que dejan inéditos y en el mayor incógnito el oficio o profesión para cuyo ejercicio se inhabilita.

Considerando: Que en el caso presente, en la parte dispositiva de la resolución combatida se condena al procesado a seis años y un día de inhabilitación especial, sin la menor concreción de aquello para lo que se le inhabilita, procediendo, en consecuencia, y ante la evidente vulneración de los preceptos sustantivos citados, la estimación del segundo motivo del presente recurso fundamentado en el núm. $10^{\circ}$ del art. 849 de la Ley de Enjuiciamiento Criminal, por indebida aplicación de los arts. 27 y 41 en relación con el 431, todos ellos del Código penal,

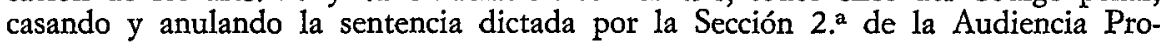
vincial de Barcelona con fecha 2 de octubre de 1980, debiendo ser sustituida por otra en la que se disponga que la inhabilitación especial impuesta se entiende referida al ejercicio de la profesión de director de revistas u otras publicaciones periódicas de la misma índole, o análoga, a la enjuiciada.

Núm. 72. Sentencia de 7 de diciembre de 1981. Contencioso-Administrativo. Sala III. Ponente, D. Espín Cánovas. CONSTITUCION.

\section{Mera cita}

Considerando: Que la recurrente impugna liquidación girada por el Ayuntamiento de Castellón de la Plana conforme a la Ordenanza Fiscal 74 sobre Impuesto municipal de Radicación, basando su impugnación en la ilegalidad del Real Decreto 3250 , de 30 de diciembre de 1976 , por falta de cobertura legal al tratarse de impuesto de nueva creación con reserva legal conforme a la Ley General Tributaria, planteándose por la Corporación municipal apelada la improcedencia de la apelación conforme al art. 94.1.b) de la Ley Jurisdiccional, al no tratarse de desviación de poder conforme al núm. $2, a$ ), del mismo precepto, en relación con el art. 729 de la Ley de Régimen Local, pero esta alegación es improcedente, ya que al impugnarse por la vía aplicativa una disposición general procede la apelación a tenor del art. 94.2.b) de la misma Ley de la Jurisdicción en relación con su art. 39, núms. 3 y 4 , como acontece en el presente caso, en que procede admitir la apelación sin referencia a la cuantía de la liquidación recurrida, y sin que sean de aplicación al caso las sentencias citadas por la Corporación recurrida como la de 20 de febrero de 1980 de esta Sala, al referirse a materia distinta a la impugnación de disposición general por la vía permitida del art. 39.4 de la Ley citada, por lo que procede conocer en apelación de la litis.

Considerando: Que la impugnación del Real Decreto de 30 de diciembre de 
1976 se funda en que la delegación legislativa concedida al Gobierno por la Ley 41, de 19 de noviembre de 1975, de Bases del Estatuto del Régimen Local, señaló el plazo de un año para llevar a cabo su articulación, por lo que los Reales Decretos-leyes 22, de 12 de noviembre, y 25, de 23 de diciembre, ambos de 1976, al haberse agotado el plazo de la delegación legislativa, no pudieron prorrogarlo, por lo que al promulgarse el Real Decreto 3250 , impugnado, le faltaba cobertura legal, no pudiendo regular materia fiscal reservada a la ley conforme a la Ley General Tributaria de 28 de diciembre de 1963, art. 10.6), impugnándose también la retroactividad de la Ordenanza fiscal recurrida al publicarse el 6 de mayo de 1977 y aplicarse desde principio de dicho año a todo su ejercicio.

ConstDerando: Que la Ley 41, de 19 de noviembre de 1975, en su disposición final 1. ${ }^{\mathrm{a}}, 2$, contiene tanto una delegación al Gobierno para articular las bases, previo informe del Consejo de Estado en pleno, en el plazo de un año desde su publicación en el Boletín Oficial del Estado, como una autorización al Gobierno para que «con igual trámite» pueda dictar «las disposiciones precisas para la puesta en vigor de aquellos puntos de la Ley que así resulte aconsejable», plazo que en relación con el texto articulado fue prorrogado sucesivamente por el Real Decretoley 22, de 12 de noviembre de 1976, hasta el 31 de diciembre de 1976, y por el Real Decreto-ley núm. 25, de 23 de diciembre de 1976, hasta el 31 de diciembre de 1977, prórrogas que se publicaron, la primera en el periódico oficial del 15 de noviembre de 1976 y la segunda en el Boletín del día 28 de diciembre del mismo año, siendo concedidas estas prórrogas al amparo de las facultades de la Ley constitutiva de las Cortes, texto refundido de 20 de abril de 1967, cuyo art. 13 autorizaba al Gobierno para proponer al Jefe del Estado la sanción de decretosleyes por razones de urgencia, por lo que las citadas prórrogas están enmarcadas en las facultades excepcionales que la citada Ley de Cortes confería al Gobierno.

ConsIDERANDo: Que el preámbulo del Real Decreto-ley 25/76, ya citado, concediendo la segunda prórroga alude a las dificultades expuestas por el Consejo de Estado en pleno para llevar a cabo en el breve plazo de la primera prórroga la ingente labor de la articulación de la Ley 41/1975 al deberse tener en cuenta también los principios inspiradores de la Ley de Reforma Política, por lo que el preámbulo citado indica que al margen de estas consideraciones quedan aquellas bases de contenida más administrativo o técnico que político, especialmente los ingresos de las Corporaciones locales, materia inaplazable aunque se deba regular con carácter provisional, razones por las que en virtud de las facultades conferidas al Gobierno por la Ley Constitutiva de las Cortes de 20 de abril de 1967, se ordena al Gobierno en su art. $2 .^{\circ}$ ponga en vigor antes del 31 de diciembre las bases 21 a 34 de la Ley $41 / 1975$ y se le autoriza para que dicte durante el año 1977, previo dictamen del Consejo de Estado, normas de desarrollo y articulación que sea necesario poner en vigor anticipadamente, génesis legislativa que por razón de su tiempo, anterior a la vigente Constitución, respetaba las Leyes Fundamentales, como era la de Cortes, por lo que no podía afirmarse le faltase cobertura legal al Decreto aqui impugnado, conforme a dicha normativa.

Considerando: Que en cuanto a la retroacción de efectos de la Ordenanza Fiscal impugnada, conforme a lo dispuesto en el art. $10^{\circ}$ y disp. final $3 .^{\mathrm{a}}$ del Real Decreto 3250/1976, de 30 de diciembre, que autoriza surtan efecto desde 1 de enero de 1977 las Ordenanzas fiscales que se aprueben en ese ejercicio dentro del ámbito de las normas de esta disposición, es preciso tener en cuenta la génesis expuesta de esta normativa que arranca de la Ley 41/1975 y sucesivas prórrogas mencionadas con fuerza de ley conforme a la citada normativa fundamental en vigor con anterioridad a la vigente Constitución, por lo que tal rango legal permite la aplicación de la retroactividad que autorice la propia Ley según el art. 2.i) del Código civil, al que también se remite el art. 29 de la Ley de Régimen Jurídico de la Administración del Estado, texto de 26 de julio de 1957, retroacción 
al principio del ejercicio ordenada por el Real Decreto impugnado en razón a la urgencia que preside esta puesta en vigor provisional de las bases citadas.

Considerando: Que por las razones que preceden debe desestimarse esta apelación, sin que existan motivos para especial pronunciamiento sobre sus costas.

Núm. 73. Sentencia de 12 de diciembre de 1981. Criminal. Ponente, F. Cotta y Márquez de Prado. ARTICULOS 18.4 Y 20 DE LA CONSTITUCION.

Libertad de expresión: límites

Limites a la libertad de expresión

Libertad de prensa

La libertad de expresión no ampara el insulto, el menosprecio o difamación de las personas investidas de los atributos de la autoridad.

CONSIDERANDO: Que si bien es cierto, con arreglo al art. 20 de la Constitución española promulgada el 29 de diciembre de 1978, que es legal el derecho de censura y crítica periodística de la actuación pública de cuantas personas ejerzan funciones de esta clase, incluso el de aquellas que se ballen investidas de los atributos de autoridad, no menos lo es que el ejercicio de ese derecbo tiene, dentro de un régimen de libertad y de responsabilidad, los limites a que obliga el respeto a dicba investidura y la consideración personal debida a quienes la encarnan, como así lo establece la propia Ley Fundamental en el núm. 4 del artículo citado y en el articulo 18 , por lo que no siendo permisible, al socaire de esos reconocidos derechos, llegar al insulto, al desprestigio, al menosprecio o a la difamación de los individuos de dichas clases, es claro que, si se bace, se incurre con tal conducta en las construcciones que la ley penal define y sanciona como delitos.

ConsIDERANDo: Que examinados los hechos de autos bajo el prisma que ofrece la doctrina que queda consignada, es patente el acierto con que los calificó el Tribunal sentenciador en la resolución objeto del recurso, ya que, aparte de que las frases y expresiones insertas en el trabajo periodístico que se copia en el resultando de hechos probados de la sentencia contradicha aluden a la ilegalidad con que fue instruido y sustanciado el proceso penal a que dicho artículo se refiere y a la conducta prevaricante de los funcionarios encargados por ministerio de la ley de la función de administrar la justicia en dicho caso, tales frases y expresiones, en sí mismas consideradas y en relación con el sentido gramatical y alcance de la totalidad del expresado trabajo, revelan, por modo a todas luces evidente, la intención dolosa que movió la voluntad del procesado de desprestigiar la dignidad, crédito, fama y honra profesional del funcionario fiscal y de los funcionarios judiciales que intervinieron en el referido proceso, pues no cabe atribuirles mayores vicios y faltas de moralidad en el desempeño de sus cargos que los de acusarles de dictar resoluciones manifiestamente injustas cuando procesaron al recurrente, de quebrantar las normas del procedimiento convirtiendo el juicio solemne en «un festival», de obstaculizar la defensa que hacía del procesado el abogado encargado de la misma, $0.1 a$ de atribuir arteramente al representante del ministerio público la defensa de los intereses de «una pandilla de sinvergüenzas» en lugar de la de los supremos intereses de la sociedad, que le está encomendada, razones todas que conllevan la desestimación del primer motivo del recurso, en cuanto que es intrascendente, a los fines del mismo, que la publicación del artículo cuestionado se hubiera hecho en la revista Naif en lugar de en Interviú, que era al parecer para la que iba destinado.

Considerando: Que el segundo de los motivos del recurso carece asimismo de 
la cimentación necesaria para su prosperabilidad, si se examina a través de todos los preceptos legales que regulan la responsabilidad criminal de las personas intervinientes en un hecho que revista caracteres de delito, pues si bien es cierto que el art. 13 del Código penal establece muy claramente que de las infracciones que se cometan por medio de la imprenta, el grabado u otra forma mecánica de reproducción, radiodifusión u otro procedimiento que facilite la publicidad, responderán criminalmente los autores, y que por autores ha de entenderse, según el siguiente art. 15 del propio texto legal, los que realmente lo hayan sido del texto, escrito o estampa publicados o difundidos, ello no quiere decir que por tales autores deba entenderse sólo a la persona física individual que suscriba con su firma el ejemplar de que se trate, sino a todos cuantos actúen en su confección por alguna de las formas o maneras que contempla el art. 14 de dicho ordenamiento y, en este sentido, no cabe la menor duda de que el recurrente es autor directo y material del delito perseguido, en cuanto que, puesto de acuerdo con el periodista que redactó, para su publicación en la prensa, el artículo injurioso por el que se le sanciona, le proporcionó y facilitó los datos necesarios para componerlo, aportándole sus propios juicios y vivencias personales, hechos que le convierten en coautor real del mismo.

Considerando: Que por todo lo expuesto procede la desestimación del recurso.

\section{Núm. 74. Auto de 17 de diciembre de 1981. Contencioso-Administrativo. Sala III. Ponente, M. Pérez Tejedor. ARTICULOS 14 Y LA SEC- CION II, CAPITULO $2 .^{\circ} ; 18$, Y 53.2 DE LA CONSTITUCION.}

Derecho a la intimidad personal

Derecbo a la inviolabilidad del domicilio

Intimidad personal

Inviolabilidad del domicilio

Reconocimiento de que los citados derechos están reconocidos en la Constitución, pero no han sido vulnerados en el presente caso.

Considerando: Que por las actuaciones de este procedimiento y las aportadas al mismo se concreta: 1. Las recurrentes han alegado ser concesionarias de unas tiendas para la venta de objetos de artesanía y regalos en la terminal internacional del aeropuerto de Madrid-Barajas; $2 .^{\circ} \mathrm{El}$ organismo autónomo del Estado «Aeropuertos Nacionales», con fecha 26 de noviembre de 1980, basándose en la extinción del plazo pactado y en necesidades de servicio, acordó resolver los contratos suscritos con las recurrentes, concediendo a éstas un plazo que finalizaría el día 31 de diciembre de 1980 a fin de que pudieran proceder al desalojo de los locales ocupados; 3. Dicho acuerdo aparece notificado el día 28 de noviembre de 1980 mediante acta notarial y entrega de los acuerdos de rescisión, advirtiendo que puede interponerse recurso de reposición contra el mismo en el plazo de un mes; 4. Todas las recurrentes, mediante escrito fechado en 26 de diciembre de 1980 , impugnaron la notificación del acuerdo, y con carácter subsidiario interpusieron recurso de reposición previo al contencioso-administrativo contra el acuerdo notificado; 5. Con fecha 2 de enero de 1981 aparece requerida una de las recurtentes para el desalojo del local que ocupaba, rogándole entregue las llaves al portador del escrito; 6..$^{\circ} \mathrm{El}$ día 18 de febrero de 1981 se precintaron los locales y durante los días 24 y 25 del mismo mes se formalizaron actas notariales de levantamiento de los precintos puestos en los locales, así como del desalojo de las mercancías existentes, procediendo a la introducción de éstas en cajas precintadas, depositadas después con relación detallada bajo la custodia del administrador del almacén del aeropuerto; $7 .^{\circ}$ Mediante escrito fechado en 25 de marzo de 1981 , remitido y reci- 
bido por correo certificado, se advierte a una de las recurrentes que tiene a su disposición las mercancías depositadas, rogándole las retirase; $80^{\circ}$ Mediante escrito fechado en 6 de mayo de 1981 las recurrentes relacionan actuaciones realizadas en 18 y 24 de febrero anterior, formulan alegaciones contra la procedencia de las mismas interesando se ordene el inmediato levantamiento de los precintos de sus tiendas y la reposición en su uso y explotación con todas sus pertenencias; $90^{\circ} \mathrm{Se}-$ gún poderes notariales otorgados por las recurrentes en distintas fechas de 1978, ninguna de ellas tenía su domicilio habitual en alguno de los locales comerciales objeto de las actuaciones impugnadas; 10 . Han impugnado las recurrentes las actuaciones referidas en recurso contencioso-administrativo que tramita la Audiencia Nacional por el procedimiento ordinario y mediante otrosí al escrito de interposición interesan, en base a lo dispuesto en los núms. 2,3 y 4 del art. $7 .^{\circ}$ de la Ley $62 / 1978$, de 26 de diciembre, se acuerde la suspensión de la ejecución o desalojo irregularmente iniciado, ordenando el levantamiento del precinto de los establecimientos; 11. La Audiencia Nacional, mediante auto de 23 de junio de 1981, acordó no haber lugar a continuar el procedimiento por los trámites especiales a cuyo amparo se inició, y no ha lugar tampoco a acordar la suspensión de la ejecución del acto, cuya petición podrá, en todo caso, reiterarse en el procedimiento ordinario; e interpuesto recurso de súplica contra el citado auto, resolvió por auto de 1 de octubre de 1981 desestimar el recurso de súplica y confirmar el auto recurrido.

Considerando: Que impugna el apelante la procedencia de aplicar al procedimiento especial de la Ley 62/1978 lo previsto en el art. 62 de la Ley Reguladora de esta Jurisdicción, y alega que la Administración con sus actuaciones ha atentado contra los derechos fundamentales garantizados por la Constitución de inviolabilidad de domicilio e intimidad personal.

ConsIderando: Que nuestra Constitución, al garantizar en su art. 18 el derecho a la intimidad personal y a la inviolabilidad de domicilio tiene precedentes en Constituciones anteriores de nuestra patria, pues ya la de 1812 en su art. 306, la de 1837 en su art. $7^{\circ}$, asi como los arts. 6 de la Constitución de 1876 y 31 de la de 1931 establecieron preceptos análogos; lo que, por otra parte, no es sino muestra de un sistema protector de derechos fundamentales que con muy diversas singladuras ha ido avanzando desde fórmulas de Derecho romano, pasando por normas del ius gentium, remodeladas durante la Edad Media, que recogió el Derecho internacional en sus primeras manifestaciones, de lo que es reflejo la obra del teólogo y jurista español Francisco de Vitoria, hasta llegar al 10 de diciembre de 1948, cuando la Asamblea General de la Organización de las Naciones Unidas aprobó y proclamó solemnemente la Declaración Universal de los Derechos Humanos, recomendando a todos los Estados miembros que la hicieran pública; de cuyo conjunto normativo se llega a la consecuencia que lo así regulado se refiere muy concretamente a derechos y libertades del hombre a fin de preservar la dignidad y el valor de la persona humana, pero cuidando de advertir, como hace expresamente la aludida Declaración Universal, que el ejercicio de tales derechos y el disfrute de las libertades así garantizadas están sujetas a las limitaciones establecidas por la ley, con el único fin de asegurar el reconocimiento y el respeto de los derechos y libertades de los demás y de satisfacer las justas exigencias de la moral, del orden público y del bienestar general en una sociedad democrática; estableciendo a este efecto el art. 12 de la misma Declaración Universal de los Derechos Humanos que nadie será objeto de injerencias arbitrarias en su vida privada, su familia, su domicilio o su correspondencia, ni de ataques a su honra o a su reputación, y toda persona tiene derecho a la protección de la ley contra tales injerencias o ataques.

Considerando: Que de conformidad con lo previsto en el art. 53.2 de la Constitución, la tutela de las libertades $y$ derechos fundamentales reconocidos en la 
misma podrá ser recabada por un procedimiento basado en los principios de preferencia y sumariedad, concretando el art. $10^{\circ}$ de la Ley 62/1978, de 26 de diciembre, en concordancia con la disposición transitoria 25.2 de la Ley Orgánica del Tribunal Constitucional, que quedan comprendidos en el ámbito de este procedimiento especial la protección de los derechos reconocidos por el art. 14 y la sección 1. ${ }^{a}$ del capitulo 2. de la Constitución; y estima el auto recurrido que la interposición del proceso especial tuvo lugar de modo paralelo al de otro común seguido ante la misma Sala, contra los mismos actos de la Administración pública, concretados en la denegación presunta de una reclamación en la que se pedía el levantamiento del precinto de unas tiendas instaladas en la terminal internacional del aeropuerto de Barajas y la reposición en la explotación con todas sus pertenencias; actos obstativos de la actividad comercial que se habían realizado el día 18 de febrero de 1981, como consecuencia de una resolución administrativa de 26 de noviembre de 1980 que acorđó la resolución de los contratos invocados como título de ocupación de los locales comerciales por las recurrentes; lo que, según el mismo auto recurrido, con toda evidencia, y sin perjuicio de la legalidad o ilegalidad de las actuaciones administrativas, no afecta a ninguno de los derechos tutelados por el procedimiento especial promovido y con aplicación supletoria, prevista en el artículo 6.1 de la Ley 62/1978, del art. 62 de la Ley Reguladora de esta Jurisdicción determina la declaración de inadmisibilidad del recurso.

CONSIDERANDO: Que los caracteres atribuidos por la normativa aplicable a este procedimiento especial, así como la finalidad específica atribuida al mismo de garantizar el ejercicio de los derechos fundamentales de la persona con trámites y efectos singulares, exigen como lógica e ineludible consecuencia no desnaturalizar la norma legal ni el procedimiento, evitando aplicar éste a la defensa y garantía de derechos que carezcan de aquella naturaleza específica; siendo para ello trámite idóneo y aplicable, según lo previsto por el art. 6 de la Ley 62/1978, el previsto por el art. 62 de la Ley Reguladora de esta Jurisdicción, aunque limitado, como el precepto legal exige, al supuesto de que aparezca de modo inequívoco y manifiesto, que no ha lugar a la admisión del recurso especial.

ConSIDERANDo: Que, a efectos de la inviolabilidad del domicilio, alegada por el apelante, habrán de interpretarse las normas aplicables teniendo en cuenta la definición contenida en el art. 40 del Código civil, pues, según dispone éste en su art. 3.3, las disposiciones del mismo se aplicarán como supletorias en las materias regidas por otras leyes y, por tanto, habrá de estimarse como domicilio de las personas naturales el lugar de su residencia habitual, lo que equivale o es sinónimo de morada o vivienda fija y permanente; sin que, en consecuencia, pueda haberse atentado contra este derecho mediante actuaciones en locales comerciales separados de la residencia habitual.

ConsIDERANDO: Que el derecho de intimidad personal garantizado por la Constitución ha de consideratse referido a evitar las injerencias arbitrarias en la vida privada de una persona, su familia, honra o reputación a que se refiere el art. 12 de la Declaración Universal de Derechos Humanos; pero es evidente que ninguna de tales injerencias deriva de la ejecución del acto administrativo notificado a las recurrentes y cuya ejecución, prevista como procedente en la normativa aplicable, aparece realizada atendiendo estrictamente a su finalidad, sin inmiscuirse en particularidades ajenas a la misma, aunque no se prejuzga aquí en forma alguna otros aspectos del procedimiento administrativo impugnado, ni la legalidad o ilegalidad del mismo a otros efectos.

CONSIDERANDO: Que si por las actuaciones del expediente administrativo y por las de este procedimiento especial se deduce la evidencia de que ninguno de los derechos fundamentales definidos en la Constitución, y en particular los de intimidad personal $e$ inviolabilidad de domicilio, invocados por la parte apelante, ban sido afectados por las actuaciones de la Administración, procede desestimar el re- 
curso contencioso-administrativo especial y confirmar la resolución recurrida por baber sido adoptada en trámite adecuado y conforme a Derecbo.

\section{Núm. 75. Sentencia de 18 de diciembre de 1981. Contencioso-Administrativo. Sala $V$. Ponente, P. García Manzano. ARTICULO 9.3 DE LA CONS- TITUCION.}

\section{Principio de seguridad jurídica}

El principio no tiene aplicación al caso concreto.

Considerando: Que la cuestión controvertida se ciñe, desde las opuestas perspectivas del abogado del Estado apelante y de los expropiados adheridos a la apelación, a la procedencia o no de incrementar el justiprecio de las parcelas 25,35 , 62 y 67 , sitas las dos primeras en término municipal de Sevilla y las otras dos en el de Camas, afectadas por el Area de Actuación Urbanística urgente (abreviadamente, ACTUR) de la Cartuja de Sevilla, con un incremento porcentual del 39,2 por 100 como efectuó la sentencia apelada de la Audiencia Nacional con base en el art. 99 (en la actualidad 112) de la Ley del Suelo de 12 de mayo de 1956, postulando el representante de la Administración que tal actualización es improcedente al ser inaplicable dicho precepto, mientras que los expropiados impetran de esta Sala una extensión del referido pronunciamiento de la decisión judicial recurrida, prolongándolo hasta el momento del pago, es decir, no limitando la operación actualizadora o revisora del justiprecio hasta fines del año 1974, como hizo la sentencia combatida, sino indagando el porcentaje de actualización y aplicándolo en función del período temporal comprendido entre el 25 de noviembre de 1971 en que se efectuó la delimitación de dicha ACTUR hasta el momento del pago del justiprecio, pretensiones que envuelven, en rigor, la cuestión del alcance y pertinente aplicación de dicho art. 99 de la Ley del Suelo.

CONSIDERANDO: Que ba de comenzarse por afirmar, con base en el principio de que las instituciones juridicas y las técnicas que las instrumentan no son fungibles o intercambiables, sino que cada una ba de aplicarse a los específicos supuestos de becho para los que el ordenamiento jurídico las bizo surgir, baciendo así operante el principio de seguridad jurídica que la Constitución consagra en su art. 9, apartado 3, ha de comenzarse afirmando que los intereses legales por demora en la fijación del justiprecio del art. 56 de la Ley de Expropiación y la técnica revisora de valoraciones preestablecidas, aplicables a la valoración de terrenos en expropiaciones urbanísticas, del art. 99 de la Ley del Suelo, no pueden entre sí sustituirse ni aplicarse indiscriminadamente, por responder a finalidad diversa: la primera obedece al deseo del legislador de evitar dilaciones en la determinación del justiprecio, siendo acicate para la pronta fijación de éste la responsabilidad por mora mediante el pago de intereses sobre el justiprecio a partir de un lapso temporal que exceda de seis meses desde que se inició la expropiación, mientras que la segunda responde sólo en valoración de terrenos y en valoraciones generales o previas en el sentido que luego se dirá, a evitar que durante el largo período de vigencia de las valoraciones urbanísticas así configuradas, de diez años, éstas sufran desfase económico con relación a factores ajenos a la especulación, restableciendo o actualizando aquel valor; de aquí que, en lo que al caso concierne, no sea acertada la sentencia recurrida cuando queriendo paliar la depreciación económica que acarrea el desfase temporal entre la fecha a que viene referida la tasación, el 25 de noviembre de 1971, en que se delimitó la ACTUR, y la de tasación individualizada de los terrenos, por Orden Ministerial de 28 de septiembre de 1974, así como la posterior fecha del pago de dicho justiprecio, acude no a los intereses moratorios 
del art. 56 citado, sino a la técnica revisora establecida en el tan repetido art. 99 de la Ley Urbanística, sin una previa averiguación de si en el caso litigioso concurren los supuestos configuradores de la aplicación de este precepto, por lo que situados en esta inicial premisa de razonamiento, que ya estableciera la sentencia de esta Sala de 10 de marzo de 1981, no puede compartirse la fundamentación de la sentencia apelada, en el concreto extremo controvertido, ni los pronunciamien. tos que respecto al mismo se contienen (declaraciones $2 .^{a}$ y $3 .^{a}$ ) en el fallo de dicha decisión judicial.

Considerando: Que con los requisitos o presupuestos del art. 99 que antes han quedado fijados, es decir, el constreñimiento a la valoración de terrenos pura y simplemente, con exclusión de vuelos, mejoras y cualquier otra merma patrimonial que no sea la estricta privación de suelo, y la aplicación limitada a valoraciones generales o preestablecidas para los terrenos de una zona o sector en que se actúa por vía expropiatoria, es decir, a los supuestos en que se trata de valores prefijados mediante cuadro de precios máximos y mínimos o de índices municipales de valoración del suelo, la declaración de la sentencia apelada ha de rechazarse; pues, en efecto, por un lado, en el pronunciamiento segundo del fallo se aplica el porcentaje del 39,2 por 100 de actualización no sólo al valor de los terre. nos de las cuatro parcelas afectadas, sino al valor total o justiprecio global en cantidad de 57.836 .460 pesetas sobre las que aplica dicho porcentaje revisor, cantidad esta total que incluye también los vuelos, construcciones y las llamadas mejoras agrícolas que integran la indemnización expropiatoria; y de otro lado, se aplica sobre valoración de terrenos, tales como los de las parcelas 62 y 67 , sitos en término municipal de Camas (Sevilla), que, carentes del Plan General de Ordenación urbana, no disponía a la sazón, ni otra cosa consta, de índice municipal de valoración ni de Decreto aprobatorio de cuadros de precios máximos y mínimos, por lo que, por de pronto, habría que excluir de la aplicada actualización u operación revisora efectuada en el seno del proceso de primera instancia, a) el valor o justiprecio de las parcelas 62 y 67 , sitas en Camas, al no serles aplicable el art. 99 por ausencia del presupuesto básico, y b) el valor o justiprecio de los vuelos, construcciones, etc., de las otras dos parcelas, las 25 y 35 , radicadas en término de Sevilla, dada la extensión improcedente que respecto a estos elementos produce la sentencia apelada, quedando por dilucidar si, en cuanto a lo que es estrictamente suelo de estas dos parcelas 25 y 35 , se puede aplicar el porcentaje corrector o de actualización del 39,2 por 100 al contar la ciudad de Sevilla con índice municipal de valoración del suelo, aprobado por Decreto de 11 de mayo de 1967 (publicado en el Boletín Oficial del Estado de 6 de junio siguiente), extremo que se analiza a continuación.

Considerando: Que para la entrada en juego del art. 99, de constante referencia, se precisa, desde el lado formal, una actuación de oficio de la Administración y una reclamación (petición en terminología legal) de cualquier propietario afectado, y aunque aquí pudiera suscitarse la duda de si los expropiados plantearon formalmente dicha instancia revisora al formular su recurso de reposición -en el que invocaban expresamente el precepto-, lo indubitable es que una correcta aplicación de la operación actualizadora del art. 99 ha de recaer sobre precios o valores generalizados de modo previo a la tasación individualizada del suelo de concretas fincas, y que actúan respecto a esta tasación como justiprecios automáticos según el art. $20^{\circ}$, apartado 5 , de la Ley 52/1962, de 21 de julio, tal como ha declarado la jurisprudencia - sentencias, entre otras, de 1 de marzo y 26 de noviembre de 1973, con cita de otras-; y si bien en este caso los terrenos sitos en el término municipal de Sevilla tenían aprobado índice municipal de valoración del suelo mediante el Decreto antes aludido, en la valoración del suelo de estas parcelas núms. 25 y 35 no consta que la Administración gestora procediese a una aplicación automática de dichos índices, ni siquiera con las modificaciones ulterio- 
res pertinentes -art. 26.1 del Decreto de 21 de febrero de 1963 -, pues a pesar de que a ello venía obligada en principio por imperativo de lo dispuesto específicamente para las actuaciones urbanísticas urgentes por el art. $4 .^{\circ}, 1, a$ ) del Decretoley $7 / 1970$, de 27 de junio, regulador de aquéllas, no aparece de lo actuado que el Instituto Nacional de Urbanización aplicase de hecho los precios comprendidos en tales índices, ni consta tampoco que los señalados por la Sala de instancia con base en el informe técnico recaído al recurso de reposición sean inferiores a los preconstituidos en el repetido índice municipal, y ello hace caer por su base la procedencia de la actualización, máxime si se atiende a lo dispuesto por el citado artículo $4 .^{\circ}$, ap. e), puesto en relación con el c) del mismo precepto del aludido Decreto-ley $7 / 1970$, ya que al ser dichos terrenos calificados como suelo rústico, la tasación procedente no es la del apartado a) de los índices, sino la del valor expectante con la edificabilidad máxima permitida por el Decreto aprobatorio de la delimitación, y como los terrenos, en definitiva, fueron tasados por dicho valor expectante, no obstante su carácter rústico, en aplicación no del automatismo de valores preconstituidos en el índice, sino obteniendo el precio de los criterios correspondiente al valor expectante de la Ley del Suelo y de su complementario anexo de coeficientes - Decreto de 21 de agosto de $1956-$, que opera como valor residual mínimo según el citado ap. $e$ ) del art. $4 .^{\circ}$, no ha lugar a la entrada en juego de un precepto, cual el reiterado art. 99, diseñado para el traslado automático a las tasaciones individualizadas de valores previamente fijados, ya desfasados económicamente, lo que es el caso enjuiciado.

Considerando: Que como ya establecía la sentencia de esta Sala de 10 de marzo de 1981, en caso similar al presente, al revocarse la actualización del artículo 99, por su improcedencia, ha de darse lugar, en cambio, a los intereses legales de demora de los arts. 56 y 57 de la Ley de Expropiación, por ser concepto de producción automática o ex lege, y declarar que procede el abono de los del art. 56 por demora en la fijación del justiprecio desde los seis meses siguientes a la publicación del Decreto de delimitación, es decir, desde el 28 de mayo de 1972 hasta el 28 de septiembre de 1974 en que se determinó administrativamente el justiprecio $y$, en su caso, los del pago desde los seis meses siguientes a esta última fecha hasta el total y efectivo pago del justiprecio señalado, esto por virtud de lo prevenido en el art. 57 de la Ley de Expropiación.

Considerando: Que no ha lugar a especial condena en costas, dado lo dispuesto por el art. 131.1 de la Ley de la Jurisdicción.

\section{Núm. 76. Sentencia de 21 de diciembre de 1981. Criminal. Sala II. Ponente, L. Vivas Marzal. ARTICULO 15 DE LA CONSTITUCION.}

Pena de muerte: abolición

Considerando $1 .^{\circ}$ : Que el art. 145, párr. 2. , de la Ley de Enjuiciamiento Criminal sigue prescribiendo, pues no se ha derogado expresamente, que en las Audiencias, para dictar sentencias en las causas en las que se hubiere pedido pena de muerte o cadena o reclusión perpetua, será precisa la intervención de cinco magistrados. Pero, suprimidas la cadena y reclusión perpetuas en los Códigos de 1932 y 1944, se suscitó la cuestión de si babia otra pena privativa de libertad, de las subsistentes, que pudiera equipararse a las citadas a efectos de composición pentapartida del tribunal provincial, y más tarde, al suprimir el art. 15 de la Constitución de 1978 la pena de muerte, se renovó y acreció la duda, la cual ba sido disipada por este Tribunal con criterios no siempre uniformes -véanse, verbigracia, las sentencias de 24 de mayo de 1965 y 21 de noviembre de 1969 y autos de 29 de marzo, 20 de abril y 29 de noviembre del mismo año-, justificándose 
las vacilaciones, pues el problema puede dilucidarse de un triple modo: a) inaplicación, en todo caso, del meritado art. 145 ; b) operancia del mismo cuando las acusaciones han solicitado la pena de reclusión mayor en cualquier extensión, y c) aplicación del precepto cuando lo pedido por las acusaciones fuera la pena de reclusión mayor en el límite superior de su grado máximo, esto es, treinta años de dicha reclusión; habiendo prevalecido y preponderado, en los últimos años, esta última tesis, que es la más racional y procedente.

ConSIDERANDO 2.0: Que en el caso presente, el ministerio fiscal solicitó ante la Audiencia como pena máxima la de veintiún años de reclusión mayor, pena que la acusación particular, en sus conclusiones, elevó a veinticuatro años, siendo pues evidente que, ante estas calificaciones, obró correctamente la Audiencia de origen, al constituirse con tres magistrados, procediendo, por tanto, la repulsión del tercer motivo de forma - único de los admitidos - del recurso interpuesto por los acusados al amparo del núm. 5 del art. 851 de la Ley de Enjuiciamiento Criminal.

\section{Comentario}

Véase comentario al auto de 9 de octubre de 1980, núm. 22 del Repertorio de 1980.

\section{Núm. 77. Sentencia de 22 de diciembre de 1981. Contencioso-Administrativo. Sala III. Ponente, D. Espín Cánovas. ARTICULO 47 DE LA CONS- TITUCION.}

\section{Urbanismo}

Acción urbanistica: plusvalias

Plusvalías: acción urbanística

Reconocimiento del principio establecido en el artículo 47 de la Constitución.

Considerando: Que la parte apelante impugna la sentencia en relación con la superficie que debe quedar excluida de la imposición por existir una explotación agrícola-forestal, pues mientras la resolución del Tribunal Económico-Administrativo provincial decide que no se aplica el arbitrio al 75 por 100 de la supetficie, en cambio la sentencia apelada estima que sólo queda exceptuado el 20 por 100 de ella, alegándose por el defensor de la Administración General que debe surtir efecto el dictamen del arquitecto al servicio de Hacienda y que el objeto social de la empresa gravada, aunque se trata de sociedad urbanizadora, comprende la adquisición de terrenos agrícolas que puedan llegar a ser urbanizables, pero estos argumentos ya fueron tenidos en cuenta en la sentencia recurrida al valorar el conjunto de los medios probatorios que ofrece el expediente administrativo, como el plano topográfico e informe acompañado por la empresa reclamante, y a la vista del conjunto de pruebas.

Considerando: Que reiterada doctrina de esta Sala exige prueba de la existencia de una explotación agrícola o forestal que demuestre su intensidad y rentabilidad, pues se trata de una excepción a la regla general de sujeción al arbitrio de incremiento del valor de los terrenos cuyo fundamento de reparto equitativo y justo de tales incrementos está reconocido en el ordenamiento español por la Ley de Régimen Local de 24 de junio de 1955 , y en la actualidad expresamente reconocido en la vigente Constitución de 1978, en su art. 47, al ordenar que la comunidad participará en las plusvalías que genera la acción urbanistica de los entes públicos, normas que justifican que la superficie exceptuada del arbitrio haya de probarse debidamente, compartiendo esta Sala la apreciación que hace la sentencia 
apelada del quantum exceptuado, que se fija en el 20 por 100 del total de los terrenos, por lo que procede desestimar la apelación sin pronunciamiento sobre las costas.

Núm. 78. Sentencia de 26 de diciembre de 1981. Criminal. Sala II. Ponente, M. Gómez de Liaño y Cobaleda. ARTICULo 24. DE LA CONSTITUCION.

Principio de que nadie puede ser condenado sin ser oído

Derecho a la defensa: garantías

Reconocimiento y aplicación del principio de que nadie puede ser condenado sin ser oído.

Considerando 3.०: Que una vez admitida la condición de responsable civil directo al asegurador o entidad aseguradora, como consecuencia del delito realizado a través de una conducta con resultado lesivo cubierto por el contrato del seguro concertado con el autor de la infracción penal, la acción civil podrá ejercitarse juntamente con la penal, de acuerdo con el art. 108 de la Ley de Enjuiciamiento Criminal, pudiendo venir el asegurador al proceso durante el período sumarial por el cauce legal del art. 615 de la citada Ley Procesal, en cuanto que se trata de un tercero responsable civilmente, que aunque no adquiere su condición de los artículos del Código penal, sí lo es en virtud del delito que se enjuicia mediante una legislación complementaria, surgida de la complejidad que encierra el uso y utilización de vehículos de motor, por lo que en aplicación de la ley por analogía es susceptible, máxime si se tiene en cuenta un predominante carácter civil, siendo necesario para que exista condena el que haya sido parte en el proceso, como exigencia imprescindible del principio de que nadie puede ser conde. nado sin ser oído $y$ de las garantías procesales que toda persona ba de tener para la defensa de sus derechos, conforme se determina en las leyes de procedimiento $y$ se recoge en el art. 24 de la Constitución, y que la acción se ejercite con el contenido suficiente para que la pretensión pueda ser objeto de debate o discusión $y$ decisión en el proceso.

Núm. 79. Sentencia de 29 de diciembre de 1981. Criminal. Sala II. Ponente, J. Latour Brotons. ARTICULOS 14 Y 25 DE LA CONSTITUCION.

Principio de igualdad Condenado: derechos

El principio de igualdad afecta al tratamiento pospenitenciario, pero no a las repercu-' siones que los antecedentes puedan tener como agravantes.

Considerando: Que, como ya ha precisado la doctrina de esta Sala - sentencias de 20 de febrero, 8 de junio y 19 de octubre últimos-, la Ley Orgánica $1 / 1979$, de 26 de septiembre, General Penitenciaria (sobre no reunir las condiciones precisas para provocar la derogación de la circunstancia agravante 15 del artículo 10 del Código penal, conforme a las prescripciones del art. 2, punto 2, del Código civil)-, el párr. 2. ${ }^{\circ}$ del art. 73 de dicha Ley Orgánica, que expresamente se invoca en el primero de los motivos articulados por la vía del 849 de la Ley de Enjuiciamiento Criminal, tan sólo está proyectado al futuro tratamiento pospenitenciario del penado que hubiere cumplido su condena, en el sentido de que sus antecedentes no podrán ser; en ningún caso, motivo de discriminación: 
social o jurídica, respondiendo así a los postulados de la Constitución, contenidos en los arts. 14 y 25, así como de la propia Ley General Penitenciaria en sus artículos 16 y 63, pero sin que en ningún caso puedan provocar la derogación, ni expresa ni tácita, de la agravante indicada en proceso posterior.

ConsIDERANDo: Que en este mismo orden de ideas, y como prueba evidente de lo que se acaba de decir, reafirmando la subsistencia de la agravante indicada, pese a la publicación de la Ley Orgánica General Penitenciaria, es muy de tener en cuenta que disposición posterior a ésta, concretamente la Ley Orgánica 10/1980, de 11 de noviembre, sobre enjuiciamiento oral de delitos dolosos menos graves y flagrantes, y que al fin y a la postre sirve de interpretación auténtica, mantiene la agravante de reincidencia en el art. $1 .^{\circ}, 2,1^{\circ}$, al exceptuar del ámbito de dicha Ley, entre otros, el supuesto de que por razón de antecedentes penales puedan imponerse penas cuya duración exceda de seis años, que se dará en el supuesto de la regla $6 .^{\mathrm{a}}$ del art. 61 , que por apreciación de la multirreincidencia permiten elevar las penas de presidio y prisión menores, cuyo máximo es el de seis años, a las inmediatamente superiores en grado.

Considerando: Que la cancelación de antecedentes penales, y los indudables beneficios que supone la reforma de la Ley $81 / 1979$, de 28 de noviembre, al adicionar el párr. $30^{\circ}$ al núm. 15 del art. 10 del Código penal, requiere la previa cancelación de los antecedentes penales, mediante la instrucción del correspondiente expediente unido al transcurso de los plazos que en dicho párrafo se establecen en función del párr. $30^{\circ}$ del art. 118 del mismo cuerpo legal —sentencias de 27 de enero, 10 de febrero y 25 de junio últimos-, y sin que en ningún caso pueda procederse de oficio por los tribunales ante la carencia de precepto o disposición que a ello obligue.

Considerando: Que, por todo ello, procede desestimar el único motivo del recurso, articulado por el cauce formal del núm. $10^{\circ}$ del art. 849 de la Ley de Enjuiciamiento Criminal, y en el que se denuncia la indebida aplicación de la circunstancia 15 del art. 10 del Código penal, con los demás pronunciamientos legales que tal desestimación conlleva.

\section{B) Resoluciones de la Dirección General de los Registros y del Notariado}

\section{R. 1. Resolución de 14 de enero de 1981.}

\section{Nacionalidad}

Cita el artículo 11 de la Constitución entre los artículos estudiados.

ConsIDERANDo: Que son hechos probados en el expediente los siguientes: a) que la interesada, alemana de origen, adquirió automáticamente la nacionalidad española como consecuencia de su matrimonio con ciudadano español, celebrado en 1961 ; b) que no obstante lo anterior, conservó y sigue conservando su nacionalidad originaria, de acuerdo con la legíslación alemana, y c) que en 6 de abril de 1979 afirma ante el Consulado «que conserva su nacionalidad alemana» y que además tiene adquirida la española; y que «el 21 de octubre de 1976, acogiéndose a la nueva legislación dictada en la República Federal alemana, solicitó y obtuvo la nacionalidad alemana para sus hijos».

Considerando: Que la especial situación de las mujeres extranjeras, casadas con español antes de la entrada en vigor de la Ley de 2 de mayo de 1975, fue abordada por el párrafo segundo de la disposición transitoria de esta Ley, a cuyo tenor: «El régimen establecido en la nueva redacción del artículo 21 del Código civil, será también aplicable a la mujer extranjera casada con español antes de la 
entrada en vigor de la presente Ley y, en consecuencia, podrá recuperar su anterior nacionalidad con arreglo a su ley de origen»;

Considerando: Que la interpretación de este precepto - a todas luces confuso- ha sido llevada a cabo por la Circular de esta Dirección de 22 de mayo de 1975 (epígrafe V), así como por la Instrucción de 11 de diciembre del propio año, cuya doctrina puede sintetizarse del modo siguiente: 1) Las mujeres casadas, que se encuentren en la situación expresada, adquirieron la nacionalidad española y ha de reputarse a todos los efectos que la continúan ostentando, mientras no conste debidamente que hayan incurrido en causa legal de pérdida; 2) Esta pérdida de la nacionalidad española se producirá cuando la mujer, después de la entrada en vigor de la Ley citada, haya recuperado su nacionalidad primitiva o haya consentido en conservarla, siempre que así resulte de una declaración expresa de su voluntad o de una conducta libre, inequívoca y concluyente que la implique, y 3) En estos casos la pérdida - que debe ser objeto de inscripción- se habrá producido de pleno derecho y sin necesidad de que concurran los requisitos que para la eficacia de la pérdida en otros supuestos exige el artículo 22 del Código civil;

CoNSIDERANDO: Que este resultado interpretativo tiene su fundamento en el hecho cierto de que el legislador español no puede pretender regular cuestiones ajenas a su competencia, como serían en este caso los requisitos para adquirir o recuperar una nacionalidad extranjera, de modo que cuando aquella disposición transitoria señala que esas mujeres casadas pueden recuperar su nacionalidad anterior, hay que entender forzosamente que lo que se regula es un modo especial de pérdida de la nacionalidad española; se trata con ello de conseguir la efectividad, respecto de tales extranjeras casadas con españoles, de los principios básicos del «régimen establecido en la nueva redacción del artículo 21 del Códiga», como son que el matrimonio no debe influir por sí sólo en la nacionalidad y que depende de la opción del cónyuge extranjero el que sea o no español como su consorte;

Considerando: Que si la indicada pérdida de la nacionalidad española se produce cuando la mujer casada con español readquiere por su voluntad su nacionalidad originaria, el mismo efecto habrá de producirse, por identidad de razón, cuando la mujer, de acuerdo con su legislación primitiva, opta claramente por mantener la nacionalidad que, no obstante el matrimonio con español y la consiguiente adquisición de la nacionalidad española, le asignaba la respectiva legislación extranjera;

Considerando: Que esta conclusión no constituye ninguna novedad del ordenamiento español ni de la doctrina de la Dirección sobre este punto, puesto que se trata solamente de la aplicación a este supuesto especial del criterio general sobre la pérdida de la nacionalidad española, por asentimiento voluntario a una nacionalidad extranjera; en efecto, y con la única salvedad de no exigirse en este caso los requisitos que para la eficacia de la pérdida impone el artículo 22 del Código civil, es ya doctrina muy reiterada del Centro Directivo que la pérdida de la nacionalidad española por adquisición voluntaria de otra nacionalidad, a que se refiere el citado artículo 22, tiene lugar en cuanto el español capaz asiente voluntariamente a la nacionalidad extranjera que viniere ostentando, sin que se requiera forma especial para esta aceptación, que puede manifestarse expresa o tácitamente, a través de actos libres y concluyentes;

Considerando: Que este resultado es el único congruente con la idea de que pasar voluntariamente a ser miembro de otra comunidad nacional «no es compatible, en la concepción vigente, con los deberes de fidelidad a la nación y con el carácter que de sujeto de poder político sobre los destinos de ella tiene, al menos en potencia, todo miembro de la comunidad española: lo que no excluye que el Estado español, no los individuos, establezca con determinadas comunidades na- 
cionales afines una cierta intercomunicación» (cfr. Resoluciones de 8 de junio y de 19 de julio de 1973); concepción esta que se manifiesta en el Código, tanto al regular la adquisición o readquisición voluntaria de nacionalidad española, puesto que se exige la renuncia previa a la nacionalidad (cfr. arts. 18, 19, 24 y 25 del Código civil), y en concreto al regular la adquisición por razón de matrimonio (cfr. art. 21, que se refiere al art. 19), como al regular la pérdida por adquisición voluntaria de otra nacionalidad (cfr. art. 22 del Código civil); y que está presente también en la misma Constitución, ya que en su artículo 11 presupone que sólo por excepción la adquisición voluntaria de la nacionalidad extranjera no comportará la pérdida de la nacionalidad española;

ConsIDERANDo: Que en este supuesto, sin embargo, no parece acreditada la voluntad de doña Ellen de querer conservar la nacionalidad alemana, con el carácter indubitado que, a efectos de pérdida de la nacionalidad española, debe exigirse: 1. Porque las manifestaciones realizadas en este expediente no son por sí concluyentes, ya que expresan meramente un hecho independiente de la voluntad: que la ley alemana le atribuye la nacionalidad alemana y, a lo sumo, un deseo, el de conservar las dos nacionalidades, lo que no equivale a la expresa e incondicionada declaración de querer conservar la nacionalidad alemana; $2 .^{\circ}$ Porque solicitar y obtener la nacionalidad alemana para los hijos no es por sí tampoco concluyente en el sentido indicado, ya que no se ha acreditado que sea necesario para que los hijos adquieran tal nacionalidad que la madre sea alemana al tiempo de solicitar tal nacionalidad para sus hijos, pues pudo haber bastado que, conforme a la ley alemana; la madre fuera alemana en el momento en que los hijos nacieron, aunque perdiera esta nacionalidad después; y la voluntad que valora, para la pérdida, la ley española no es la referida a una nacionalidad pasada, atribuida con anterioridad a la ley española de 1975, sino a la nacionalidad que, con posterioridad a esta ley, le podía seguir asignando la ley alemana;

Considerando: Que con arreglo al artículo 98 de la Ley del Registro Civil, son gratuitas estas actuaciones;

Esta Dirección General ha acordado, de conformidad con la propuesta reglamentaria:

1. Estimar el recurso y, con revocación del auto apelado, declarar no acreditada la pérdida de la nacionalidad española sin prejuzgar que no la puede haber perdido por acto de voluntad concluyente aún no acreditado.

2..$^{\circ}$ Ordenar cancelar la inscripción de pérdida.

3. Declarar la gratuidad de todas las actuaciones seguidas.

\section{R. 2. Resolución de 28 de enero de 1981.}

\section{Matrimonio civil}

Cita de la Constitución.

Constderando: Que el objeto de este recurso versa sobre si será posible autorizar el matrimonio civil que desean contraer en España un español soltero y una española en la que se dan las siguientes circunstancias: 1) Contrajo matrimonio canónico con un súbdito holandés en Vigo en 1957, adquiriendo por este hecho la nacionalidad holandesa y perdiendo la española; 2) En ese mismo año un tribunal holandés dictó sentencia de divorcio de dicho matrimonio, y 3) La interesada, que conservaba la nacionalidad holandesa, recuperó en forma legal su anterior nacionalidad española en 1977;

ConsIDERANDo: Que el estado civil de un extranjero se rige por su ley personal (art. 9.1 del Código civil), sin que haya ya motivos después de la Constitu- 
ción, por las razones que expuso la Resolución de este Centro de 6 de abril de 1979, para estimar que la excepción de orden público internacional (cfr. art. 12.3 del Código civil) impide reconocer eficacia en España a una sentencia extranjera de divorcio vincular aunque haya recaído sobre un matrimonio canónico; consiguientemente, la interesada, si está divorciada vincularmente según su ley nacional, tenía capacidad para contraer nuevo matrimonio, y esta conclusión ha de seguir siendo válida por. más que haya recuperado la nacionalidad española, pues es evidente que esta recuperación no puede implicar cambio en el estado civil del sujeto, y no puede haber atisbo alguno de fraude de ley (cfr. art. 12.4 del Código civil) cuando la aplicación de la ley extranjera ha tenido lugar no por una naturalización voluntaria previa al divorcio, sino por una adquisición impuesta de la nacionalidad holandesa por razón del matrimonio mismo, con pérdida automática también de la nacionalidad española (cfr. art. 23.3 del Código civil, en su redacción por la Ley de 15 de julio de 1954);

Considerando: Que, conforme a los artículos 86 del Código civil y 244 del Reglamento del Registro Civil, la contrayente debe presentar la prueba del divorcio vincular del anterior matrimonio, el cual, y por ser un hecho aún no inscrito en el Registro español, puede ser acreditado por otros medios distintos a la certificación registral, como puede ser el testimonio de la sentencia de divorcio vincular y con el carácter de firme (caracteres ambos que no resultan de la traducción aportada) o el correspondiente certificado consular; pero entonces, y en cumpli- miento de lo dispuesto en el artículo $2:^{\circ}$ de la Ley del Registro Civil, será requisito indispensable para la admisión de estas pruebas que, previa o simultáneamente, se haya instado la inscripción de la disolución en el Registro español, que todavía no ha sido practicada, no obstante tratarse de un hecho sujeto a inscripción conforme a lo. establecido en el artículo 66 del Reglamento;

Considerando: Que, con arreglo a los artículos 98 de la Ley y 372 de su Reglamento, son de oficio las costas de estas actuaciones;

Esta Dirección General ha acordado, de conformidad con la propuesta reglamentaria:

1..$^{\circ}$ Revocar el auto apelado.

2. Declarar que no existe obstáculo por razón del matrimonio anterior, con tal que se justifique debidamente su disolución por sentencia firme del tribunal holandés, y que previa o simultáneamente se ha promovido, bien ante el Registro competente, bien a través del Registro Civil del domicilio, la inscripción de la sentencia del divorcio vincular, sin que sea necesario esperar a la práctica de esta inscripción ni completar los requisitos de la correspondiente solicitud.

3. Declarar la gratuidad de las presentes actuaciones.

\section{R. 3. Resolución de 6 de abril de 1979.}

\section{Matrimonio civil}

\section{Artículos 16 y 32 de la Constitución.}

Considerando: Que la consulta elevada a este Centro por el juez de primera instancia número 2 de Cartagena, conforme a lo permitido por el artículo 250 del Reglamento del Registro Civil, se dirige a determinar si el juez encargado correspondiente podrá autorizar el matrimonio civil que intentan celebrar una española, viuda, y un súbdito francés divorciado vincularmente según su ley personal de un matrimonio anterior, contraído tanto en forma civil como canónica.

Considerando: Que la última doctrina sobre la cuestión planteada, contenida en las Resoluciones de 23 de marzo, 5 de abril y 24 de agosto de 1976 y en la 
sentencia del Tribunal Supremo de 22 de noviembre de 1977, ha consistido en distinguir según que el matrimonio anterior del extranjero, disuelto por el divorcio vincular, merezca para el Derecho español la calificación de simple unión civil o de matrimonio canónico, puesto que sólo en este segundo caso se estimaba que la excepción de orden público recogida en el artículo 12.3 del Código civil impedía conceder eficacia directa a la sentencia extranjera de divorcio, con la consecuencia de deber reputarse subsistente el impedimento de ligamen derivado del primer matrimonio, y esto a pesar de que el extranjero, conforme a su ley personal (cfr. art. 9.1 del Código), gozaba en principio de la capacidad necesaria para acceder a nuevas nupcias.

ConsIDERANDo: Que no hay que olvidar que la excepción de orden público es, por su propia naturaleza, de carácter variable, elástico y flexible, puesto que si, según la jurisprudencia, el orden público está constituido por «aquellos principios jurídicos, públicos y privados, políticos y económicos, morales e incluso religiosos, que son absolutamente indispensables para la conservación del orden social en un pueblo y en una época determinada» (sentencia del Tribunal Supremo de 5 de abril de 1966), es indudable su carácter relativo, ligado a la concepción social y política de cada momento histórico; aparte de que, en todo caso, en el campo internacional la excepción de orden público, por suponer una quiebra a la comunidad jurídica universal, ha de ser interpretada y aplicada restrictivamente.

Considerando: Que es innecesario resaltar el profundo cambio político-social, y también jurídico, que refleja y precisa la promulgación de la Constitución española; concretamente en el régimen del matrimonio, la indisolubilidad de éste -que ya tenía inflexiones y matizaciones en el propio Derecho interno, a pesar de la declaración del artículo 52 del Código- ya no tiene rango constitucional y basta, a estos efectos, comparar el antiguo artículo 22 del Fuero de los Españoles con el artículo 32.2 de la nueva Constitución; y no es posible hoy estimar que sólo respecto del matrimonio canónico su indisolubilidad es de orden público, pues los principios constitucionales de no confesionalidad del Estado y de libertad religiosa (art. 16 de la Constitución) impiden tales discriminaciones civiles por razones religiosas.

Considerando: Que, de otro lado, los artículos XXIII y XXIV del Concordato, todavía formalmente vigente, entre la Santa Sede y el Estado español, recogidos fundamentalmente en los artículos 75 y 80 a 82 del Código, únicamente contienen el compromiso internacional de España de reconocer los efectos civiles y la competencia exclusiva de la Iglesia en cuanto a los matrimonios canónicos en el ámbito en que el Estado español, conforme a sus normas de colisión, se estima competente y no pueden alcanzar a los matrimonios extranjeros excluidos de la competencia de las autoridades de España y regidos por la ley o leyes nacionales de los contrayentes (art. 9.1 del Código civil).

Esta Dirección General ha acordado, de conformidad con la propuesta reglamentaria: resolver la consulta en el sentido de que actualmente la excepción de orden público no impide el matrimonio civil entre una española viuda y un francés divorciado, independientemente del carácter canónico o civil del matrimonio anterior de éste, si está disuelto, según su ley personal, por la sentencia firme de divorcio vincular. 


\section{R. 4. Resolución de 30 de junio de 1981.}

\section{Matrimonio civil}

Artículos 14, 16, 53 y disposición derogatoria de la Constitución.

Considerando: Que carece de toda consideración la apreciación del recurrente de que un matrimonio civil celebrado en Francia, según la forma local, por un español en 1971 es nulo por defecto de forma, por aplicación del artículo 101.4 del Código civil en relación con el artículo 100 del propio cuerpo legal, pues esta interpretación -en modo alguno segura antes de la nueva Ley del Registro Civil, a la vista de lo que entonces establecían los artículos 70 de la antigua Ley del Registro Civil y 11 del Código civil- ha sido paladinamente desechada por el artículo 73 de la actual Ley del Registro Civil, en vigor ya cuando el matrimonio se celebró, que admite explícitamente la validez del matrimonio contraído en el extranjero con arreglo a la forma del país, supeditando sólo su inscripción en el Registro español a la tramitación del expediente gubernativo que desarrolla el artículo 249 del Reglamento del Registro Civil.

Considerando: Que el principio de no discriminación por razón de religión (art. 14 de la Constitución) y de aconfesionalidad del Estado (art. 16), de aplicación inmediata al entrar en vigor la Constitución (cfr. arts. 53 y disposición derogatoria 3), impiden hoy que la competencia del Estado en relación con la celebración de un matrimonio en forma civil, y en concreto que su inscripción en el Registro Civil, pueda seguir dependiendo de la prueba de la acatolicidad del contrayente español, como, en cambio, ocurría en 1971 según los principios y disposiciones entonces vigentes; pero es que además no puede ser atendida por ser contraria al comportamiento moral exigible, la invocación del contrayente, el cual primero libre y solemnemente consintió el matrimonio y, por consecuencia, comprometió por ello gravemente los bienes más íntimos de la otra parte y proclamó socialmente la eficacia general de la relación matrimonial, y ahora, para desdecirse del matrimonio, pretende hacer valer la necesidad de probar previamente una actitud moral subjetiva, la no profesión del catolicismo, que de otra parte él no ha invocado ni demostrado, y que incluso está contradicha por la celebración sólo en forma civil de acto tan importante en una vida religiosa como es el matrimonio;

Considerando: Que en modo alguno pueden tenerse en cuenta las restantes alegaciones del contrayente en el sentido de que la unión fue meramente circunstancial, puesto que no es este expediente la vía adecuada para decidir sobre un hipotético vicio de consentimiento, aparte de que todas las pruebas acompañadas justifican precisamente lo contrario: la persistencia de la convivencia matrimonial durante varios años y el nacimiento de dos hijos, inscritos por declaración del propio padre como hijos de tal matrimonio;

ConSIDERANDo: Que el expediente es gratuito, conforme al artículo 98 de la Ley del Registro Civil, pero deben imponerse al recurrente, por aplicación del artículo 371 del Reglamento, las costas de los dos recursos que ha entablado, al ser palpable su temeridad y su propósito fraudulento, por sí o mal aleccionado, de desligarse de un matrimonio al que accedió libremente, por el camino de oponerse a su obligada inscripción.

Esta Dirección General ha acordado, de conformidad con la propuesta reglamentaria:

1. Confirmar el auto apelado.

2. Declarar la gratuidad del expediente.

3. Imponer al recurrente el pago de las costas de los recursos que ha interpuesto. 


\section{R. 5. Resolución de 2 de octubre de 1981.}

Nacionalidad

Cita el artículo 11 de la Constitución entre los artículos estudiados.

Considerando: Que es doctrina reiterada de este Centro Directivo que, a los efectos de la pérdida de la nacionalidad española conforme al artículo 22 del Código civil, se asimilan la adquisición voluntaria de otra nacionalidad y el asentimiento voluntario que el súbdito español, con capacidad según la ley española, realice expresa o tácitamente a la nacionalidad extranjera que se le hubiere atribuido anteriormente, incluso iure soli en el momento de su nacimiento;

Considerando: Que en este segundo supuesto son requisitos necesarios para que la pérdida produzca efectos, conforme al citado artículo 22 del Código civil, que el interesado haya residido fuera de España al menos durante los tres años inmediatamente anteriores a la fecha de aquel asentimiento $\mathrm{y}$, además, en cuanto a los varones, que no estén sujetos al servicio militar en período activo, salvo que medie dispensa del Gobierno;

Considerando: Que estos requisitos aquí no concurren, puesto que el solicitante, de veintiún años de edad al formular su petición, residía antes -y sigue residiendo- en España y no ha acreditado tampoco no estar sujeto al servicio militar en período activo;

ConsIderando: Que el artículo 23.1 del Código civil establece también la pérdida de la nacionalidad española para los que entren al servicio de las armas en un Estado extranjero contra la prohibición expresa del Jefe del Estado español, y esta prohibición fue dictada en modo general por el Decreto de 28 de diciembre de 1967, pero es indudable que no entra en ese concepto de servicio de armas la circunstancia de que el peticionario haya cumplido, dentro del mismo territorio español, determinadas exigencias buroctáticas en orden a los deberes militares con Venezuela;

CONSIDERANDo: Que el expediente es gratuito, pero el recurso devenga derechos, conforme al artículo 371 del Reglamento, por apreciarse temeridad en el recurrente;

Esta Dirección General ha acordado, de conformidad con la propuesta reglamentaria:

1..$^{\circ}$ Desestimar el recurso interpuesto.

2. Imponer al promotor el pago de las costas del recurso, sin perjuicio de la gratuidad del expediente. 